\title{
First continuous phosphate record from Greenland ice cores
}

\section{H. A. Kjær ${ }^{1}$, A. Svensson ${ }^{1}$, P. Vallelonga ${ }^{1}$, E. Kettner ${ }^{1}$, S. Schüpbach ${ }^{2}$, M. Bigler ${ }^{2}$, J. P. Steffensen ${ }^{1}$, and M. E. Hansson ${ }^{3}$ \\ ${ }^{1}$ Centre for Ice and Climate, Niels Bohr Institute, University of Copenhagen, Juliane Maries vej 30, 2100 Copenhagen, Denmark \\ ${ }^{2}$ Climate and Environmental Physics, Physics Institute and Oeschger Centre for Climate Change Research, University of Bern, Sidlerstrasse 5, 3012 Bern, Switzerland \\ ${ }^{3}$ Physical Geography and Quaternary Geology, Stockholm University, Stockholm, Sweden}

Received: 26 October 2011 - Accepted: 5 November 2011 - Published: 18 November 2011

Correspondence to: H. A. Kjær (hellek@fys.ku.dk)

Published by Copernicus Publications on behalf of the European Geosciences Union.
7, 3959-3989, 2011

First phosphate data from Greenland ice cores

H. A. Kjær et al.

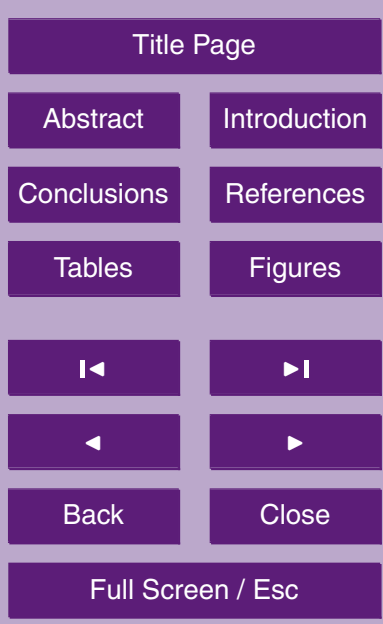

Printer-friendly Version

Interactive Discussion 


\section{Abstract}

A continuous and highly sensitive absorption method for detection of soluble phosphate in ice cores has been developed using a molybdate reagent and a $2 \mathrm{~m}$ liquid waveguide (LWCC). The method is optimized to meet the low concentrations of phosphate 5 in Greenland ice, it has a detection limit of around $0.1 \mathrm{ppb}$ and a depth resolution of approximately $2 \mathrm{~cm}$. The new method has been applied to obtain phosphate concentrations from segments of two Northern Greenland ice cores: from a shallow firn core covering the most recent $120 \mathrm{yr}$ and from the recently obtained deep NEEM ice core in which sections from the late glacial period have been analysed. Phosphate coninfluence in the most recent ice. In the glacial part of the NEEM ice core concentrations in the tions in the cold stadial periods are significantly higher, in the range of 6-24 ppb, while interstadial ice concentrations are around $2 \mathrm{ppb}$. In the shallow firn core, a strong correlation between concentrations of phosphate and insoluble dust suggests a similar deposition pattern for phosphate and dust. In the glacial ice, phosphate and dust also correlate quite strongly, however it is most likely that this correlation originates from the phosphate binding to dust during transport, with only a fraction coming directly from dust. Additionally a constant ratio between phosphate and potassium concentrations shows evidence of a possible biogenic land source.

\section{Introduction}

Phosphorus $(P)$ is an essential macro nutrient important for all living organisms and is present in DNA and bones. Earth's biological systems have been dependent on $\mathrm{P}$ since the beginning of life (Filippelli, 2008; Paytan and McLaughlin, 2007). As a result of this dependence $P$ recycling is very efficient in earth's biological systems (Tiessen, 1995).
7, 3959-3989, 2011

\section{First phosphate data from Greenland ice cores}

H. A. Kjær et al.

\section{Title Page}

Abstract

Introduction

Conclusions

Tables

References

Figures

14

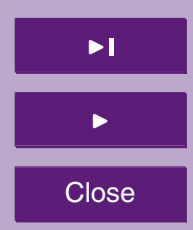

Back

Close

Full Screen / Esc

Printer-friendly Version

Interactive Discussion

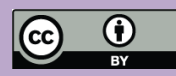


is intensively debated reaching from the opinion that $P$ is a controlling factor to $P$ being important but not comparable to other macro nutrients such as nitrate (Falkowski et al., 1998; Elser et al., 2007; Worsfold et al., 2008; Tamburini and Föllmi, 2009).

In the earth's crust the mean $P$ concentration is $1200 \mathrm{mg} \mathrm{kg}^{-1}$ (Tiessen, 1995). Phos5 phate $\left(\mathrm{PO}_{4}^{3-}\right)$ is generated by weathering and transported to the oceans mainly by rivers, where $\mathrm{PO}_{4}^{3-}$ concentrations are in the range of 2 to $110 \mathrm{ppb}$ (Concright et al., 2000). $\mathrm{PO}_{4}^{3-}$ is most abundant in polar waters and regions of upwelling, where concentrations are generally lower during summer seasons in the surface waters (Concright et al., 2000; Levitus et al., 1993).

10 As $\mathrm{P}$ does not have a gaseous phase it is transported through the atmosphere as particulate matter or as $\mathrm{PO}_{4}^{3-}$ (Graham and Duce, 1982; Baker et al., 2006; Mahowald et al., 2008; Paytan and McLaughlin, 2007). The atmospheric transport as determined in a model study by Mahowald et al. (2008) of $P$ is dominated by mineral dust (82\%), with sea salt, primary biogenic particles, volcanoes and human activity accounting for 5 the remainder. For $\mathrm{PO}_{4}^{3-}$, the soluble part of total $\mathrm{P}$, mineral dust accounts for only $48 \%$ of the global atmospheric transport, biogenic particles account for $38 \%$, volcanism accounts for $1.3 \%$ and sea salt merely $2 \%$, while anthropogenic activity is believed to account for about $14 \%$. In some countries of mid- and high-latitude Europe (Finland, Norway, Belgium), there is evidence of a high fraction of $P$ in coarse aerosols $(>1 \mu \mathrm{m})$ 20 having a biogenic origin (Mahowald et al., 2008). Although atmospheric transport only accounts for a small part of the $\mathrm{P}$ cycle, it is important for nourishing primary production in the remote ocean (Paytan and McLaughlin, 2007; Mahowald et al., 2008).

Very little information on the amount of $\mathrm{P}$ and $\mathrm{PO}_{4}^{3-}$ in the Arctic exists and even less information is available on the concentrations in glaciers. Edwards et al. (2007) 25 measured $P$ on the Greenland ice sheet in snow and firn and found average concentrations of $0.25 \mathrm{ppb} P$ over the last $50 \mathrm{yr}$. They found a dramatic increase in $\mathrm{P}$ during the period 1990-2005 suggested to correspond to increased forest fire burning. Analysis of glacier run off from smaller glaciers show $\mathrm{P}$ concentrations between $0.31 \mathrm{ppb}$ and $145 \mathrm{ppb}$ (Chillrud et al., 1994; Tockner et al., 2002) and the soluble fraction of $P$ was
7, 3959-3989, 2011

\section{First phosphate data from Greenland ice cores}

H. A. Kjær et al.
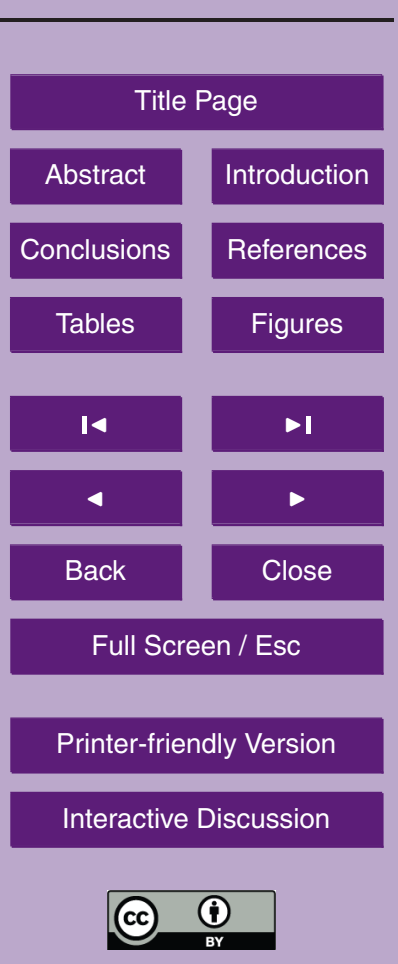
found to be low, $0.2 \%$ to $4.3 \%$, in a study by Hodson et al. (2004) looking at particulate melt water from glaciers in France, Pakistan, Svalbard and Sweden.

The cycling of $P$ is suggested to vary greatly over glacial-interglacial cycles (Mahowald et al., 2008; Filippelli, 2008). In glacial times sea level changes have exposed 5 shelf areas allowing $P$ deposition on shelves to be re-introduced to the global cycle. This so-called shelf nutrient hypothesis has been observed in marine records (Tamburini and Föllmi, 2009; Filippelli, 2008; Delaney, 2000; Elderfield and Rickaby, 2000). In the Holocene a general trend of increasing mineral $P$ has been observed as a sign of cooling conditions in alpine regions, but several short-lived changes has been observed 10 as well (Filippelli et al., 2006). In recent times, the natural cycling of $\mathrm{PO}_{4}^{3-}$ has been impacted by anthropogenic activities, such as the use of $\mathrm{P}$ as a fertilizer (Schlesinger, 1991; Tiessen, 1995; Diaz and Rosenberg, 2008; Oelkers and Valsami-Jones, 2008; Filippelli, 2008) and forest fire burning (Filippelli, 2008; Paytan and McLaughlin, 2007; Bolin et al., 1981).

Over geological time scales $P$ is believed to be the limiting nutrient in oceans. The increased level of Fe believed to be transported to the ocean as an effect of the general increased dust level in the atmosphere during glacial times, supports denitrification processes in the oceans by increasing levels of cyanobacteria which fix Nitrogen. Eventually the amount of phytoplankton would be $\mathrm{PO}_{4}^{3-}$ limited, thus carbon sequestra-

20 tion would have been $\mathrm{PO}_{4}^{3-}$ limited, too (Falkowski et al., 1998; Paytan and McLaughlin, 2007).

Ice cores provide an archive of past climate in high temporal resolution. Greenland ice cores cover the last glacial cycle (NGRIP members, 2004), whereas Antarctic ice cores archive almost a million years of past climate (EPICA community members, 25 2004). During the second half of the last glacial period, Greenland ice cores show evidence of important climate variability with generally colder climate conditions, stadial periods (GS), being abruptly interrupted by milder interstadial periods (GI), the so-called Dansgaard-Oeschger events.
7, 3959-3989, 2011

\section{First phosphate data from Greenland ice cores}

H. A. Kjær et al.

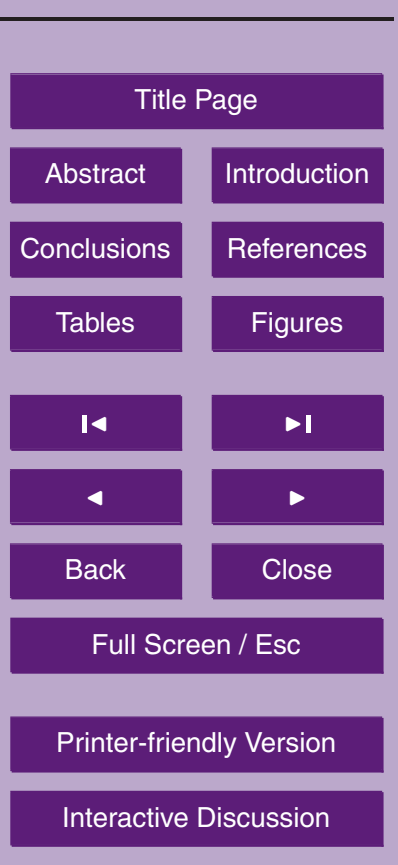

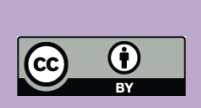


Such past climate conditions can be reconstructed from the impurities in Greenland ice cores. Insoluble dust provides information on atmospheric transport patterns and dust source regions (Ruth, 2005; Svensson et al., 2000), sea salt components are related to the oceanic environment and wind speed (de Angelis et al., 1997; Fischer 5 et al., 2007), sulphate concentration peaks often reflect volcanic activity (Zielinski et al., 1996), and biogenic activity, such as forest fires or marine bioproductivity can be detected as well (Fuhrer et al., 1996) as is the case for anthropogenic impacts (McConnell et al., 2007a,b). Furthermore, there is a pronounced seasonality in the deposition of these impurities-insoluble dust is regularly deposited in the boreal spring, forest fire 10 proxies in summer and sea salts in winter (Legrand and Mayewski, 1997).

In general, the coldest periods during the glacial have the highest loads of almost all impurities. Over stadial-interstadial cycles concentrations change by a factor of 10 for dust proxies, while sea salt proxies vary by a factor of 3 (Hansson, 1994; Mayewski et al., 1997). The dust load is especially high in the period around 23-26 ka, proba-

bly due to a combination of lowered sea level
conditions (Ruth, 2005; Maher et al., 2010).

In this pilot study, $\mathrm{PO}_{4}^{3-}$ analyses have been performed on two North Greenland ice cores, a map is provided in Fig. 1. Preliminary measurements were performed on a shallow firn core $\left(76.45^{\circ} \mathrm{N}, 44.77^{\circ} \mathrm{W}, 2771 \mathrm{~m}\right.$ a.s.l.) drilled in 2007 during a traverse expedition between the NGRIP and NEEM ice core drilling sites. However only a few sections between $6 \mathrm{~m}$ and $34 \mathrm{~m}$ depth were analysed. Later, glacial sections of the NEEM ice core $\left(77.45^{\circ} \mathrm{N} 51.0^{\circ} \mathrm{W}, 2484 \mathrm{~m}\right.$ a.s.I.), a major international deep drilling project initiated in 2007, were analysed in the field in 2010. They cover the depth $1607.7 \mathrm{~m}$ to $1764.9 \mathrm{~m}$ corresponding to the late glacial period ( 22 to $37 \mathrm{ka}$ ).
7, 3959-3989, 2011

\section{First phosphate data from Greenland ice cores}

H. A. Kjær et al.

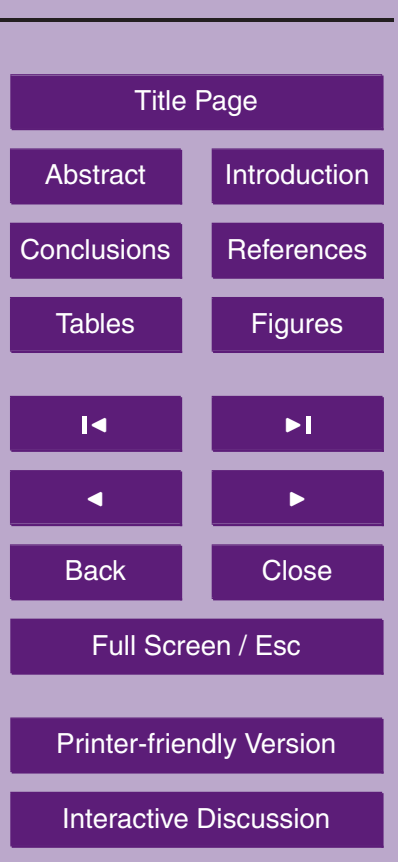




\section{Experimental methods}

\subsection{Phosphate detection for a CFA-set up}

7, 3959-3989, 2011

In recent times Continuous Flow Analysis (CFA) has become a widely applied method for detection of dust and chemical impurities in ice cores, mainly because of the high 5 resolution provided by the method as well as improved contamination control and sample throughput (Sigg et al., 1994; Röthlisberger et al., 2000; Kreutz, 2006).

For the shallow firn core analyses the new $\mathrm{PO}_{4}^{3-}$ detection system was connected to the existing CFA system in Copenhagen (Bigler et al., 2011). For the NEEM ice core analyses the system was attached to the Bern CFA setup (Kaufmann et al., 2008) in 10 the field. In both cases an air-segmented continuous flow spectrophotometric method was implemented for the determination of $\mathrm{PO}_{4}^{3-}$ concentrations (Fig. 2). The flow rates were different between the two setups, as the Copenhagen set-up is optimized for high resolution measurements, while the Bern set-up is optimized to measure many species efficiently in deep ice cores (Bigler et al., 2011).

15 The $\mathrm{PO}_{4}^{3-}$ detection system is adapted from the method by Murphy and Riley (1958) that was later optimized by Zhang et al. (1999) and Zhang and Chi (2002). A 12molybdophosphoric acid is formed from the reaction of $\mathrm{PO}_{4}^{3-}$ in the sample with molybdate in an acidic solution in the presence of potassium antimony tartrate. The 12molybdophosphoric acid is subsequently reduced by ascorbic acid to a phosphomolyb20 denum blue complex. The absorbance of the phosphomolybdenum blue complex is measured at $710 \mathrm{~nm}$ by a $2000 \mathrm{~S}$ spectrometer, with the sample illuminated by a DTMINI-2GS deuterium tungsten halogen light source (both Ocean Optics, Dunedin FL, USA). To enhance the limit of detection (LOD), absorbance was measured in a two metre liquid waveguide capillary cell (LWCC, Ocean Optics, Dunedin FL, USA) with an 25 inner volume of only $0.5 \mathrm{ml}$ as suggested by Zhang and Chi (2002).

The sensitivity of the method was further increased by heating the mixed reagents to $65^{\circ} \mathrm{C}$, although sample heating increases the risk for interferences resulting from the production of precipitates of silicate and arsenate (Zhang and Chi, 2002; Gimbert

First phosphate data from Greenland ice cores

H. A. Kjær et al.
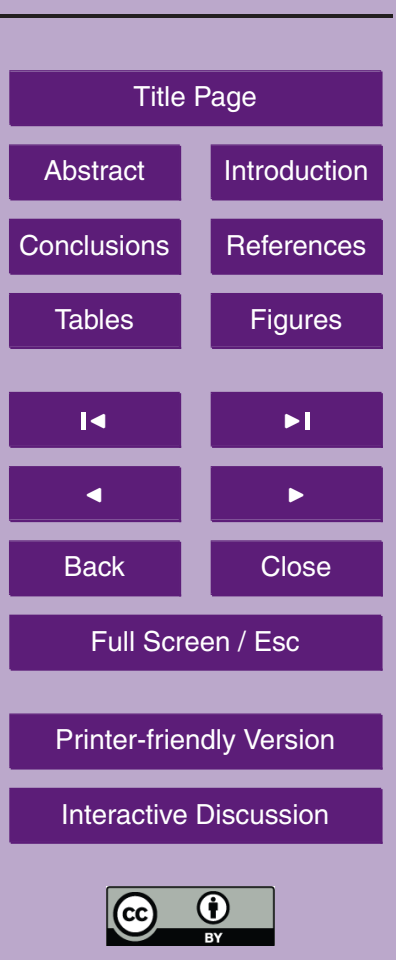
and Worsfold, 2007; Nollet, 2007; Ma et al., 2009). Such interferences are possible, as these ions react with molybdenum blue to create the same blue colour as the reaction with $\mathrm{PO}_{4}^{3-}$. Zhang et al. (1999) estimated the extent of the potential silicate interference using the mean crustal silica abundance: assuming the same abundance 5 for dust ( $27.7 \%$ by weight), the maximum concentration of silicate in ice cores during the glacial maximum is $20 \mu \mathrm{M}$. As this would result in an apparent $\mathrm{PO}_{4}^{3-}$ concentration of $0.6 \mu \mathrm{M}(0.6 \mathrm{ppt})$, such an interference would not affect our results significantly. Arsenate is probably not present in ice cores in quantities large enough to perturb the measurements of $\mathrm{PO}_{4}^{3-}$, but in such a case thiosulfate could be added to the reagent 10 to preferentially react with Arsenate (Zhang and Chi, 2002). Thiosulfate addition was not done in this study.

Various flow rates, mixing lengths, detection wavelengths, spectrum integration, and filter types were tested and optimized to increase detection of low concentrations of $\mathrm{PO}_{4}^{3-}$. Optimal flow rates, used for the shallow firn core analyses, were found to be $151.7 \mathrm{ml} \mathrm{min}^{-1}$ for sample, $0.15 \mathrm{ml} \mathrm{min}^{-1}$ for reagent and buffer and $0.20 \mathrm{ml} \mathrm{min}^{-1}$ for air, which was introduced to limit sample dispersion. It is recommended that mixing occurs over at least $3 \mathrm{~m}$ of PFA tubing of a diameter of $0.5 \mathrm{~mm}$, in a heat bath with a steady temperature of about $65^{\circ} \mathrm{C}$. In front of the detection cell air was removed using a sealed debubbler (Bigler et al., 2011). Final LOD in such a set up was $0.1 \mathrm{ppb}$. The flow rates 20 applied for the detection of the NEEM ice core analyses in Greenland were $0.9 \mathrm{ml} \mathrm{min}^{-1}$ for sample, $0.08 \mathrm{ml} \mathrm{min}^{-1}$ for reagent and buffer and $0.15 \mathrm{ml} \mathrm{min}^{-1}$ for air and due to the set-up at NEEM the mixing length was increased to $5 \mathrm{~m}$ at approximately $17^{\circ} \mathrm{C}$ and $1 \mathrm{~m}$ heated to $65^{\circ} \mathrm{C}$.

A filter was introduced to remove particulates that would otherwise completely ob25 scure the LWCC. The filter consists of a $3 \mathrm{~cm}$ column with an internal volume of about $2 \mu \mathrm{l}, 2 / 3$ filled with glass wool, which succeeded in removing essentially all dust. The filter was located just prior to the LWCC to make sure that all soluble $\mathrm{PO}_{4}^{3-}$ attached to dust had time to react before detection. The filter was changed regularly depending on the dust content of the sample analysed: for the shallow firn core the filter did not 
require replacement, but for the NEEM campaign, it was changed regularly. A new filter was used after the analysis of each $9 \mathrm{~m}$ section of interstadial ice and more often, up to every $2 \mathrm{~m}$, when analysing impurity-laden stadial ice.

\subsection{Reagents and standards}

5 All samples and reagents were stored in polypropylene bottles (Nalgene Corp., Rochester NY, USA). All reagents used were of analytical grade, purchased from Merck (Darmstadt, Germany). The reagents are similar to the ones described in Zhang and Chi (2002) except for the stock ammonium molybdate, which had a higher concentration. Stock antimony potassium tartrate solution was prepared by dissolving $0.3 \mathrm{~g}$ of 10 antimony potassium tartrate in $100 \mathrm{ml}$ of deionized water. The solution was stored in a dark bottle in a refrigerator. Stock ammonium molybdate solution was prepared daily by dissolving $0.37 \mathrm{~g}$ of ammonium molybdate in $25 \mathrm{ml}$ of $5 \mathrm{~N} \mathrm{H}_{2} \mathrm{SO}_{4}$ solution, then adding $5 \mathrm{ml}$ stock antimony potassium tartrate solution, and diluting to $100 \mathrm{ml}$ with deionized water. Ascorbic acid solution was prepared daily by dissolving $0.5 \mathrm{~g}$ of ascorbic acid and $7 \mathrm{~g}$ of sodium dodecyl sulfate in $100 \mathrm{ml}$ of deionized water. A stock solution of $\mathrm{PO}_{4}^{3-}$ (999 ppm, Merck, Darmstadt, Germany) was diluted to make standards.

\section{Samples and data processing}

All measurements were calibrated using $\mathrm{PO}_{4}^{3-}$ standards with a linear fit between absorption and concentration, which is appropriate for the concentrations found in ice (Zhang and Chi, 2002). For the shallow firn core five standards were measured for every $2.75 \mathrm{~m}$ of sample, while only three standards were run for the NEEM ice core and only after every $4.4 \mathrm{~m}$ of sample.

For the NEEM analyses, variability in the baseline and system sensitivity were observed predominantly as a result of the higher impurity content of the samples. Higher $\mathrm{PO}_{4}^{3-}$ concentrations and to some extent the low flow and thus longer mixing time for
7, 3959-3989, 2011

First phosphate data from Greenland ice cores

H. A. Kjær et al.

\section{Title Page}

Abstract Introduction Conclusions References

Tables Figures

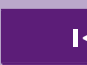

14 D

4

Back

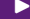

Close

Full Screen / Esc

Printer-friendly Version

Interactive Discussion

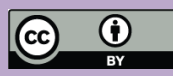


the reaction caused some coating of the tubing - observed as a steady colour change of the tubing. This behaviour was not observed during the shallow firn core analyses. This coating was possibly enhanced by a roughening of cell walls due to higher dust load. Flushing the tubing with solutions of methanol, $5 \%$ hydrochloric acid, or sodium 5 hydroxide did not remove the coating. Furthermore, the large amount of dust in the glacial samples required the filter to be changed at least once a day. It is possible that $\mathrm{PO}_{4}^{3-}$, entrained onto dust trapped in the tubing and/or the filter, may have gradually increased the concentration of $\mathrm{PO}_{4}^{3-}$ thus causing a lowered baseline over the course of each measurement. To compensate for this a linear correction of the baseline was made from start to end of each measurement (Fig. 3). The baseline correction procedure introduced an additional uncertainty to the NEEM measurements: while normally less than $2 \mathrm{ppb}$ for each run $(110 \mathrm{~cm})$, these baseline changes were occasionally up to $4 \mathrm{ppb}$ (see Table 1).

The shallow firn core measurements show brief contamination spikes at the beginning and end of each run, most likely related to handling of the ice sample. This was removed later at the signal processing stage. Such a contamination was not visible for the NEEM ice core, because of the higher concentrations detected in the ice and more careful sample preparation procedures.

The depth resolutions for the shallow firn core and the NEEM ice core analyses 20 are estimated from spectral analysis to be $1.3 \mathrm{~cm}$ and $5.7 \mathrm{~cm}$, respectively. The lower depth resolution for the NEEM ice core analyses was due to the lower flow rate and increased sample mixing time as well as due to increased coating due to higher $\mathrm{PO}_{4}^{3-}$ concentrations.

For the processing of the shallow firn core melting speed data were used to correct 25 for melt rate variations, while the NEEM ice core was processed assuming a linear melt rate, which does not cause large errors because of the high mixing already smoothing the signal. Figure 3 shows examples of raw data and calibrated data detected in the two different set-ups. The signal to noise ratio is very different for the two because of the much higher concentrations found in the NEEM ice core.
7, 3959-3989, 2011

First phosphate data from Greenland ice cores

H. A. Kjær et al.

\section{Title Page}

Abstract

Introduction

Conclusions

Tables

References

Figures

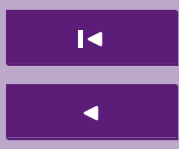

$\rightarrow 1$

Back

$\checkmark$

Close

Full Screen / Esc

Printer-friendly Version

Interactive Discussion

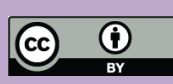


Greenland ice cores are dated to high accuracy using annual layer counting and fixed tie-points such as volcanic layers that are common to several ice cores, as well as linking to records from other palaeoarchives (Andersen et al., 2006; Rasmussen et al., 2006).

5 The shallow firn core was dated using a Heron-Langway model tuned to fit the density profile and the Laki (1783 AD) and Tambora (1815 AD) eruptions that were identified through electrical conductivity measurements. An accumulation rate of $0.181 \mathrm{~m}$ ice equivalent per year was used.

To enable comparisons between NEEM data and NGRIP potassium record, the 10 NGRIP records were transferred to NEEM depths using stratigraphic fix points at the onsets of Dansgaard-Oeschger events. This same method has been used to transfer the NGRIP chronology to NEEM. Potassium records from the GISP2 ice core were directly transferred to NEEM depths using the GISP2 dating for fix points (Mayewski et al., 1997).

\section{Shallow firn core}

From a shallow firn core covering the past $120 \mathrm{yr}$, phosphate has been determined for selected intervals. $7.75 \mathrm{~m}$ of firn were measured, covering the depths 6.05 to $7.15 \mathrm{~m}$, 8.80 to $10.45 \mathrm{~m}$ and 28.05 to $33.50 \mathrm{~m}$ as shown in Fig. 4. The mean concentration level was $0.32 \mathrm{ppb}$ with a standard deviation of $0.27 \mathrm{ppb}$ and a maximum value of $4.18 \mathrm{ppb}$. 20 This is on the same order of magnitude as the $0.25 \mathrm{ppb} P$ concentrations determined in Greenland snow $\left(71.4^{\circ} \mathrm{N}, 44^{\circ} \mathrm{W}\right.$ and $\left.65^{\circ} \mathrm{N}, 44.9^{\circ} \mathrm{W}\right)$ using ICP-MS (Edwards et al., 2007).

The $\mathrm{PO}_{4}^{3-}$ concentration is strongly correlated with dust suggesting similar sources and/or similar transport processes.

25 In the shallow firn core, $\mathrm{PO}_{4}^{3-}$ shows no apparent seasonal variation. Although $\mathrm{PO}_{4}^{3-}$ concentrations are somewhat higher in spring and winter, with means of $0.44 \pm 0.24 \mathrm{ppb}$ (standard deviation) and $0.41 \pm 0.28 \mathrm{ppb}$, respectively, summer 3968
7, 3959-3989, 2011

First phosphate data from Greenland ice cores

H. A. Kjær et al.

Title Page

Abstract

Introduction

Conclusions

Tables

References

Figures
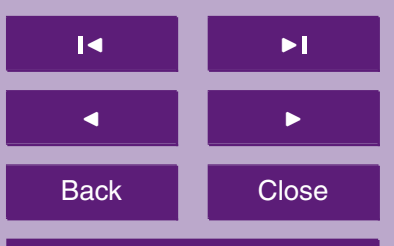

Back

Close

Full Screen / Esc

Printer-friendly Version

Interactive Discussion

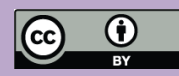


$(0.34 \pm 0.19 \mathrm{ppb})$ and autumn $(0.27 \pm 0.17 \mathrm{ppb})$ concentrations are identical within the observed error range. The seasonality was evaluated by splitting the year in four equal parts and determining each year based on an estimation of annual layer thickness as defined by the $\mathrm{NH}_{4}^{+}$summer peak. Seasonal variability in the potential sources of 5 phosphate were considered in an attempt to identify the greatest contributors. Of the oceanic sources, 2 to 3 times higher $\mathrm{PO}_{4}^{3-}$ concentrations are observed every winter in surface waters of the North Atlantic and North Pacific between $40^{\circ}$ and $70^{\circ} \mathrm{N}$. Concright et al. (2000) explained that this winter enrichment is due to the general circulation in the oceans. As a similar pattern was not observed for the firn core samples, it is likely 10 that sea salt emissions are not the main $\mathrm{PO}_{4}^{3-}$ source. To some degree the $\mathrm{PO}_{4}^{3-}$ better resembles the behaviour of dust, with a steady spring maximum. A linear fit between $\mathrm{PO}_{4}^{3-}$ and dust is best in autumn $\left(R^{2}=0.91\right)$ and spring $\left(R^{2}=0.81\right)$, while for the winter $\left(R^{2}=0.73\right)$ and summer $\left(R^{2}=0.43\right)$ the fits are weaker. As the gradients of the fits vary from about $0.3 \times 10^{4}$ in autumn, rising in the winter, $0.7 \times 10^{4}$, and summer, $0.8 \times 10^{4}$ 15 and showing the highest inclination in springtime $1.6 \times 10^{4}$ it supports different origins of dust over the year or more likely, additional phosphate sources in some seasons. It is unclear how a biogenic phosphate signal may change on seasonal scales. Mahowald et al. (2008) suggested that there would be no major seasonal changes for a biogenic $\mathrm{PO}_{4}^{3-}$ source in the tropics, but does not exclude the possibility of seasonal variations 20 in higher latitudes, with a minimum in wintertime.

The firn $\mathrm{PO}_{4}^{3-}$ record also shows some spikes coinciding with ammonium $\left(\mathrm{NH}_{4}^{+}\right)$, but not with dust (Fig. 4), suggesting occasionally a common source of the two, for example a biogenic signal. It is unlikely that the coinciding spikes of $\mathrm{NH}_{4}^{+}$and $\mathrm{PO}_{4}^{3-}$ could be evidence of a terrestrial fertilizer signal, since such a signal would be expected annually and the spikes are only visible in some years.

The results found in the 19th century firn at depths of $28 \mathrm{~m}$ to $34 \mathrm{~m}$ (approximate 1880 to $1920 \mathrm{AD}$ ) are compatible with more recent snow at depths of $6 \mathrm{~m}$ to $11 \mathrm{~m}$ (1978 to $1994 \mathrm{AD}$ ) suggesting there is minimal influence to atmospheric $\mathrm{PO}_{4}^{3-}$ from modern anthropogenic activities.
7, 3959-3989, 2011

\section{First phosphate data from Greenland ice cores}

H. A. Kjær et al.

\section{Title Page}

Abstract

Introduction

Conclusions

References

Tables

Figures

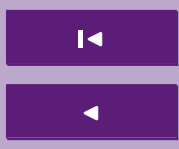

$\Delta$

Back

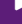

Close

Full Screen / Esc

Printer-friendly Version

Interactive Discussion

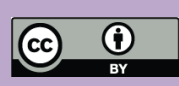




\section{NEEM deep ice core}

The NEEM $\mathrm{PO}_{4}^{3-}$ record is shown in Fig. 5 together with records of $\delta \mathrm{D}$, insoluble dust, $\mathrm{Ca}^{2+}, \mathrm{NH}_{4}^{+}, \mathrm{Na}^{+}$from NEEM measured using CFA as well as $\mathrm{K}^{+}$from the NGRIP and the GISP2 ice cores measured by Ion Chromatography (IC). NGRIP is only $365 \mathrm{~km}$ 5 from NEEM and so is likely to provide levels of $\mathrm{K}^{+}$comparable to those expected at NEEM. Due to the presence of spikes in the NGRIP $\mathrm{K}^{+}$record, GISP2 data was also included.

The NEEM $\mathrm{PO}_{4}^{3-}$ record covers sections within glacial interstadial 2 to 8 (22.4$36.8 \mathrm{kyr} \mathrm{BP}$ ). In the mild interstadial sections $(\mathrm{B}) \mathrm{PO}_{4}^{3-}$ levels are in the range 0.3 10 to $12 \mathrm{ppb}$ with mean values between 0.7 and $2.1 \mathrm{ppb}$ (Table 1). In the glacial stadials (A) the level is consistently higher with concentrations between 1.9 and $59 \mathrm{ppb}$ and the mean of the sections covered in GS (A) showed concentrations from 6.4 to $24.1 \mathrm{ppb}$. To first order $\mathrm{PO}_{4}^{3-}$ concentrations are thus negatively correlated to the temperature proxy $\delta \mathrm{D}$, with higher $\mathrm{PO}_{4}^{3-}$ concentrations during colder climatic periods.

15 The ratio between $\mathrm{PO}_{4}^{3-}$ concentrations in recent snow (the shallow firn core analysis) and those in the cold GS in the NEEM ice core is up to 200, while the mild GI show changes by a factor 16 making $\mathrm{PO}_{4}^{3-}$ comparable to other dust proxies (Steffensen, 1997; Ruth et al., 2003; Ruth, 2005; Maher et al., 2010).

A rough estimate of the maximum amount of $\mathrm{PO}_{4}^{3-}$ that could theoretically originate 20 from dust was calculated using the mean amount of dust in the coldest period from the GRIP ice core in the period GS3 $\left(7600 \mu g_{\text {dust }} / \mathrm{kg}_{\text {ice }}\right.$; Steffensen, 1997) and the global mean of $P$ in dust $\left(1200 \mathrm{mg} \mathrm{kg}^{-1}\right.$; Tiessen, 1995). Even if one assumes that $P$ is $100 \%$ soluble, unlikely given that Hodson et al. (2004) found a soluble P fraction of less than $2 \%$, we find that at most only $5.8 \mathrm{ppb} \mathrm{PO}_{4}^{3-}(\sim 24 \%)$ could be explained by dust 25 deposition in the period of GS3. Another way of estimating the theoretical amount of $P$ arriving to the ice is using the same procedure, but estimating the dust weight from the values in Table 1 using the rough relationship found in Lambert et al. (2011), namely

First phosphate data from Greenland ice cores

H. A. Kjær et al.

Title Page

Abstract Introduction

Conclusions

Tables References Figures

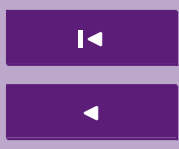
$\rightarrow 1$

Back

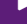

Close

Full Screen / Esc

Printer-friendly Version

Interactive Discussion

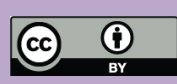


that the mass of dust relative to ice $(M)$ in $\mathrm{ng} \mathrm{g}^{-1}$ is given by $M=10^{(\log 10(D)-1.14)}$, where $D$ is the dust in particles $\mathrm{ml}^{-1}$. In this case the amount of dust is $1913 \mu \mathrm{g}_{\text {dust }} / \mathrm{kg}_{\text {ice }}$ for the period $\mathrm{A} 1$ positioned in GS3 corresponding a theoretical level of $\mathrm{PO}_{4}^{3-}$ from dust of merely $2.3 \mathrm{ppb}(\sim 10 \%)$, when assuming all $\mathrm{P}$ arriving as $\mathrm{PO}_{4}^{3-}$. It is not surprising 5 that the level is lower when calculating it based on NEEM data since the GRIP ice core is from Central Greenland, where dust levels are higher. The GRIP value is presented to give an absolute maximum value of the theoretical arrival of $\mathrm{PO}_{4}^{3-}$ originating from dust sources in GS3. For the remaining periods the amount of $\mathrm{PO}_{4}^{3-}$ that theoretically could arrive from dust determined using the Lambert method varies between $6 \%$ and the $\mathrm{PO}_{4}^{3-}$ concentrations observed in NEEM ice. The theoretical level of $\mathrm{PO}_{4}^{3-}$ arriving from dust sources to the ice is thus much lower than the percentage of global mean $\mathrm{PO}_{4}^{3-}$ arriving from dust sources determined in the model by Mahowald et al. (2008), who applied a solubility fraction of $10 \%$. It should also be noted, that the total P level in dust in aerosols vary by about $30 \%$ globally (Mahowald et al., 2008).

In order to further consider the potential sources of $\mathrm{PO}_{4}^{3-}$ present in NEEM ice, evaluations were made of correlations between $\mathrm{PO}_{4}^{3-}$ and other impurities reported in Greenland ice cores. Most impurities generally do correlate to some degree during the last glacial. Figure 6 presents high resolution data from depths 1703.30 to $1707.75 \mathrm{~m}$, with a clear correlation between $\mathrm{PO}_{4}^{3-}$, dust and soluble $\mathrm{Ca}^{2+}$. This correlation occasionally breaks down, with some dust spikes having no counterpart in $\mathrm{PO}_{4}^{3-}$ and vice versa. The relationship between $\mathrm{PO}_{4}^{3-}$ and dust was further investigated by comparing $110 \mathrm{~cm}$ mean values as shown in Fig. 7. This comparison shows a high correlation (0.83) based on $110 \mathrm{~cm}$ means, but also implies additional $\mathrm{PO}_{4}^{3-}$ sources, especially 25 when recalling the potential $\mathrm{PO}_{4}^{3-}$ contribution calculated from dust sources. Other potential explanations for variability in $\mathrm{PO}_{4}^{3-}$ - dust correlations are different sources of dust with variable soluble fractions of $\mathrm{P}$ and/or different atmospheric transport mechanisms. It is likely that $\mathrm{PO}_{4}^{3-}$ due to its high negative charge binds to positively charged
7, 3959-3989, 2011

First phosphate data from Greenland ice cores

H. A. Kjær et al.

\section{Title Page}

Abstract Introduction

Conclusions

Tables References Figures

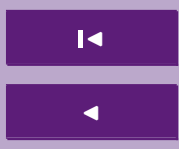
$\Delta$

Back

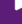

Close

Full Screen / Esc

Printer-friendly Version

Interactive Discussion

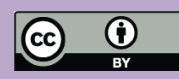


dust particles in the atmosphere and thus an increase of dust (or $\mathrm{Ca}^{2+}$ ) as observed during the glacial stadials will enhance the efficiency of $\mathrm{PO}_{4}^{3-}$ transport to the ice sheet, independent of source changes of $\mathrm{PO}_{4}^{3-}$. Based on the mass-balance calculations described earlier, it is unlikely that more than about half of the $\mathrm{PO}_{4}^{3-}$ found in the NEEM 5 ice core originates from dust, although it is likely that close to all $\mathrm{PO}_{4}^{3-}$ is co-deposited on the ice with dust.

The amount of sea salt derived $\mathrm{PO}_{4}^{3-}$ was evaluated from the $\mathrm{Cl}^{-}$level in the NGRIP ice (measured by IC) assuming that its only source was sea salt and using the fractionation coefficient between $\mathrm{Cl}^{-}$and $\mathrm{PO}_{4}^{3-}$ in sea salt, $R_{\text {seasalt }}=5.68 \times 10^{-6}$ (Gianguzza 10 et al., 2002; Concright et al., 2000). From this calculation we found that the sea salt

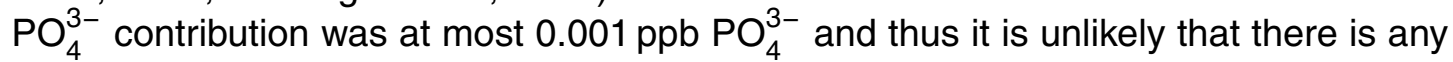
significant contribution from sea salt to the $\mathrm{PO}_{4}^{3-}$ seen in the NEEM ice core. In a multivariable box model approach to the soft tissue carbon pump by de Boer et al. (2010) the $\mathrm{PO}_{4}^{3-}$ level in the surface ocean at $70^{\circ} \mathrm{N}$ is estimated to change from a concentra15 tion of $49 \mathrm{ppb}$ during interglacial to $80 \mathrm{ppb}$ during glacial periods excluding atmospheric transport. However since $\mathrm{Cl}$ also doubles its concentration $\left(0.25\right.$ to $0.5 \mathrm{~g} \mathrm{~kg}^{-1}$, Adkins et al., 2002) the higher levels of $\mathrm{PO}_{4}^{3-}$ in surface waters do not significantly increase the calculated contribution arriving from sea areas. $\mathrm{Na}^{+}$, also a sea salt proxy though not an unambiguous one, has a correlation with $\mathrm{PO}_{4}^{3-}$ of 0.75 , based on $110 \mathrm{~cm}$ means. In 20 high resolution close up comparisons (Fig. 6) concentrations of $\mathrm{Na}^{+}$and $\mathrm{PO}_{4}^{3-}$ follow each other, but the position of spikes in the $\mathrm{PO}_{4}^{3-}$ follow dust and $\mathrm{Ca}^{2}+$ better. Further $\mathrm{Na}^{+}$lacks the prominent spikes found in $\mathrm{PO}_{4}^{3-}$ during the last glacial maximum, and $\mathrm{A} 7$ has too low a $\mathrm{Na}^{+}$concentration with respect to $\mathrm{PO}_{4}^{3-}$.

In summary the combined amounts of $\mathrm{PO}_{4}^{3-}$ theoretically arriving from sea salt and 25 dust source areas are insufficient to explain the amount of $\mathrm{PO}_{4}^{3-}$ detected in NEEM ice, thus it is likely that other sources such as biogenic emissions or volcanism are substantial contributors to the $\mathrm{PO}_{4}^{3-}$ budget.
7, 3959-3989, 2011

First phosphate data from Greenland ice cores

H. A. Kjær et al.

Title Page

Abstract Introduction

Conclusions

Tables References Figures

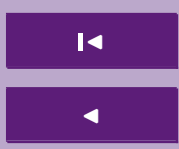
$\Delta$

Back

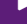

Close

Full Screen / Esc

Printer-friendly Version

Interactive Discussion

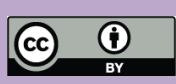


The likelihood of $\mathrm{PO}_{4}^{3-}$ inputs originating from biogenic activity was evaluated by comparison to potassium records in NGRIP and GISP2 ice cores $-\mathrm{K}^{+}$concentrations are not yet available from NEEM. The comparison of two measurement techniques (Continuous CFA; Discrete IC) applied to different ice core records (respectively: 5 NEEM; NGRIP and GISP2) introduces the possibility of bias. Downscaling is required to compare continuous measurements to discrete measurements, and different levels of impurities are sure to be found at different locations across the Greenland ice cap. From these caveats we can attempt a preliminary evaluation of phosphate sources but a more refined evaluation will not be possible until $\mathrm{K}^{+}$data are available from NEEM 10 ice.

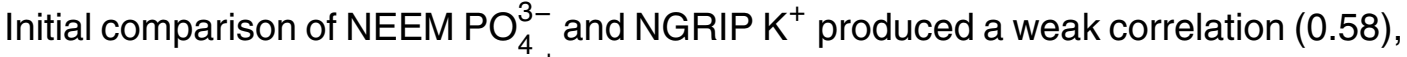
due to the presence of excess $\mathrm{K}^{+}$spikes in the NGRIP record. These spikes had a strong influence on the low $\mathrm{PO}_{4}^{3-}$ concentrations. To test whether such spikes were anomalous, the GISP2 $\mathrm{K}^{+}$record was also evaluated and used to determine which of the excess spikes in the NGRIP record could be discounted. After removing the 9 largest spikes in the NGRIP $\mathrm{K}^{+}$record, the correlation grew to 0.84 (Figs. 5 and 7). It has been suggested that simultaneous enrichments in $\mathrm{P}$ and $\mathrm{K}$ may be an indicator of aerosols of biogenic origin (Graham et al., 2003; Mahowald et al., 2008). The ratios between $\mathrm{K}^{+}$and $\mathrm{PO}_{4}^{3-}$ vary for sea salt $\left(0.03-4 \times 10^{-4}\right)$, dust $(0.05-0.10)$ and biogenic material (0.01-5.5) (Concright et al., 2000; Basile et al., 2003; Enghag, 1998; Graham et al., 2003). Comparing these ratios with those found between potassium from NGRIP or GISP2 and $\mathrm{PO}_{4}^{3-}$ from NEEM in ice $(\sim 1)$, it seems that the ratio found in the ice best follows a biogenic signal. It should however be noted that the literature on the ratio between $\mathrm{P}$ and $\mathrm{K}$ was very limited and that the biogenic ratio is based solely on land source observations.

The $\mathrm{NH}_{4}^{+}$and $\mathrm{PO}_{4}^{3-}$ records obtained in the NEEM ice core correlate by 0.75 . Looking at the high resolution plot in Fig. 6 , the $\mathrm{NH}_{4}^{+}$and $\mathrm{PO}_{4}^{3-}$ records appear to follow each other. In Fig. 7, however, the correspondence seems less convincing, especially for the low levels of $\mathrm{NH}_{4}^{+}$. The correlation between $\mathrm{NH}_{4}^{+}$and $\mathrm{PO}_{4}^{3-}$ could support a common
7, 3959-3989, 2011

First phosphate data from Greenland ice cores

H. A. Kjær et al.

\section{Title Page}

Abstract

Introduction

Conclusions

Tables References

Figures

14

$\Delta$

4

Back

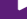

Close

Full Screen / Esc

Printer-friendly Version

Interactive Discussion

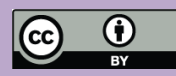


biogenic source. $\mathrm{NH}_{4}^{+}$is believed to originate from from soil and vegetation and to contain spikes originating from forest fire burning in North America (Fuhrer et al., 1996).

The shelf nutrient hypothesis is supported by the level of $\mathrm{PO}_{4}^{3-}$ detected in the ice cores. The level is highest during the colder periods, in which the sea level is lower 5 and thus more of the shelf area is exposed, however this is also the case for many of the other impurities. Closer comparison to the sea level changes determined by Sidall et al. (2010), did not clarify the matter because the record of detected $\mathrm{PO}_{4}^{3-}$ is too short for a reliable comparison, but more importantly due to the variability between different sea level estimates on short time scales.

10 The increased amount of $\mathrm{PO}_{4}^{3-}$ in glacial ice suggests that the transport of $\mathrm{P}$ was greater in glacial times, and thus the amount of fertilization of remote ocean sites most likely was also higher, potentially supporting a greater amount of primary productivity in the oceans. Unlike high nutrient low clorophyll (HNLC) waters, which are studied in detail for the possibility of fertilization by iron and other macro nutrients (Parekh et al., 15 2008), much larger expanses of open ocean are instead limited by macro nutrients such as $\mathrm{P}$, and thus may contribute significantly to glacial draw-down of $\mathrm{CO}_{2}$ (Falkowski et al., 1998; Lüthi et al., 2008; de Boer et al., 2010). However the atmospheric transport of nutrients are often not included or only included for some species when modelling past climate. And when included the nutrients are often determined based on the 20 transport of dust. This study shows that the $\mathrm{PO}_{4}^{3-}$ concentrations found in the NEEM record exceed the levels that would be expected if dust were the only $\mathrm{PO}_{4}^{3-}$ source. The high levels of $\mathrm{PO}_{4}^{3-}$ reported here for the past glacial period demonstrates the continued importance of observational data for the accurate modelling of glacial $\mathrm{CO}_{2}$ draw-down.
7, 3959-3989, 2011

\section{First phosphate data from Greenland ice cores}

H. A. Kjær et al.

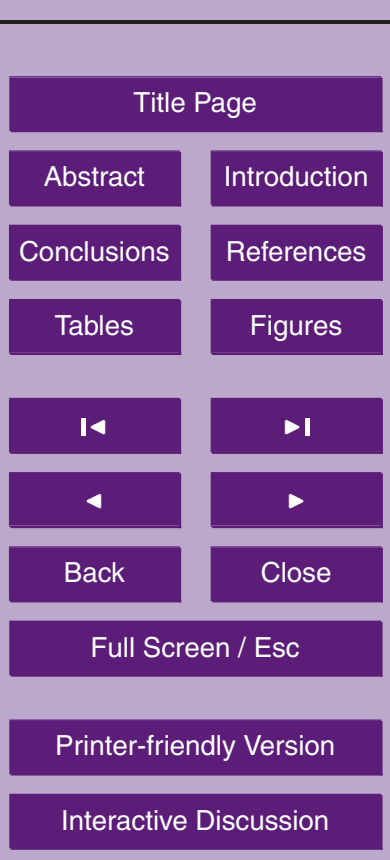




\section{Conclusions}

The first high-resolution continuous $\mathrm{PO}_{4}^{3-}$ record from a Greenland ice core has been obtained using an adapted version of the method suggested by Zhang and Chi (2002), which differs from other molybdenum blue methods by the use of a $2 \mathrm{~m}$ LWCC. A filter 5 was introduced to avoid optical interferences from dust and a heat bath was implemented to enhance the sensitivity of the method. Using this set-up concentrations down to $0.1 \mathrm{ppb} \mathrm{PO}_{4}^{3-}$ were detected.

$\mathrm{PO}_{4}^{3-}$ detected in a shallow firn core shows a weak seasonal pattern with maxima in winter and spring time and a minima in autumn. In the recent years the level was only $10 \quad 0.32 \mathrm{ppb}$. No change in $\mathrm{PO}_{4}^{3-}$ concentrations was observed from the early to late 20th century.

Higher $\mathrm{PO}_{4}^{3-}$ concentrations are found in glacial NEEM ice, demonstrating a negative correlation with temperature. Glacial stadials have in mean $\mathrm{PO}_{4}^{3-}$ levels varying between 6.4 and $24.1 \mathrm{ppb}$ with the highest level of $59 \mathrm{ppb}$ occurring in stadial 2 in coincidence with the periods of the highest dust loads. The glacial interstadial periods have much lower mean concentration level of 0.7 and $2.1 \mathrm{ppb}$. For the detection of ice with high $\mathrm{PO}_{4}^{3-}$ concentrations (glacial stadials) one could consider using a shorter LWCC, for example of about $50 \mathrm{~cm}$. According to Adornato et al. (2007) that should still be sufficient to get a LOD of $1.0 \mathrm{ppb} \mathrm{PO}_{4}^{3-}$.

A high correlation of $\mathrm{PO}_{4}^{3-}$ and dust concentrations was found in both the shallow firn core and the older NEEM ice core, with concentration changes between glacial and interglacial climates on the same order of magnitude as for other dust proxies. The high correlation to dust is partly due to dust being a source for up to half of the $\mathrm{PO}_{4}^{3-}$ and partly due to dust particles acting as a transport and/or deposition agent 25 for the $\mathrm{PO}_{4}^{3-}$ originating from other sources. Strong correlations between $\mathrm{NEEM} \mathrm{PO}_{4}^{3-}$ and NGRIP K ${ }^{+}$also suggest a common source, possibly terrestrial biogenic emissions. High resolution measurements of $\mathrm{K}^{+}$in NEEM ice are essential for the verification of this correlation and could help to determine their dominant source(s). Some common
7, 3959-3989, 2011

First phosphate data from Greenland ice cores

H. A. Kjær et al.

Title Page

Abstract

Introduction

Conclusions

Tables References

Figures

14

$\Delta$

4

Back

$\checkmark$

Close

Full Screen / Esc

Printer-friendly Version

Interactive Discussion

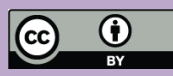


peaks between $\mathrm{PO}_{4}^{3-}$ and $\mathrm{NH}_{4}^{+}$in the firn record also suggest a biogenic source of $\mathrm{PO}_{4}^{3-}$.

The increased level of $\mathrm{PO}_{4}^{3-}$ found in glacial times suggest that transport of $\mathrm{PO}_{4}^{3-}$ in the atmosphere must have been higher, causing an increased fertilization of remote 5 oceans. The higher level of $\mathrm{PO}_{4}^{3-}$ also supported by the shelf nutrient hypothesis.

Acknowledgements. This work is a contribution to the NEEM ice core project, which is directed and organized by the Center of Ice and Climate at the Niels Bohr Institute and US NSF, Office of Polar Programs. It is supported by funding agencies and institutions in Belgium (FNRS-CFB and FWO), Canada (NRCan/GSC), China (CAS), Denmark (FIST), France (IPEV, CNRS/INSU,

10 CEA and ANR), Germany (AWI), Iceland (Rannls), Japan (NIPR), Korea (KOPRI), The Netherlands (NWO/ALW), Sweden (VR), Switzerland (SNF), UK (NERC) and the USA (US NSF, Office of Polar Programs).

\section{References}

Adkins, J. F., Mclntyre, K., and Schrag, D. P.: The salinity, temperature, and $\mathrm{d}^{18} \mathrm{O}$ of the glacial deep ocean, Science, 298, 1769-1773, 2002. 3972

Adornato, L. R., Kaltenbacher, E. K., Greenhow, D. R., and Byrne, R. H.: High resolution in situ analysis of nitrate and phosphate in the oligotrophic ocean, Environ. Sci. Technol., 41, 4045-4052, 2007. 3975

Andersen, K. K., Svensson, A., Johnsen, S. J., Rasmussen, S. O., Bigler, M., Röthlisberger, R., Ruth, U., Siggaard-Andersen, M.-L., Steffensen, J. P., Dahl-Jensen, D., Vinther, B. M., and Clausen, H. B.: The Greenland ice core chronology 2005, 15-42 ka, Part 1: constructing the time scale, Quaternary Sci. Rev., 25, 3246-3257, 2006. 3968

Baker, A. R., Jickells, T. D., Witt, M., and Linge, K. D.: Trends in the solubility of iron, aluminium, manganese and phosphorus in aerosol collected over the Atlantic Ocean, Mar. Chem., 98, 25 43-58, 2006. 3961

Basile, B., Reidel, E. J., Weinbaum, S. A., and DeJong, T. M.: Leaf potassium concentration, $\mathrm{CO}_{2}$ exchange and light interception in almond trees (Prunus dulcis (Mill) DA Webb), Sci. Hortic-Amsterdam, 98, 185-194, 2003. 3973
7, 3959-3989, 2011

\section{First phosphate data from Greenland ice cores}

H. A. Kjær et al.

\section{Title Page}

Abstract

Introduction

Conclusions

References

Tables

Figures
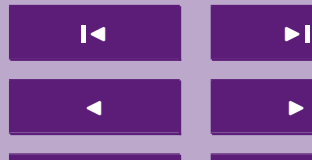

> I

Back

$\checkmark$

\section{Close}

Full Screen / Esc

Printer-friendly Version

Interactive Discussion

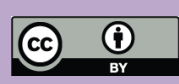


Bigler, M., Svensson, A., Kettner, E., Vallelonga, P., Nielsen, M. E., and Steffensen, J. P.: Optimization of high-resolution continuous flow analysis for transient climate signals in ice cores, Environ. Sci. Technol., 45, 4483-4489, doi:10.1021/es200118j, 2011. 3964, 3965

Bolin, B., Crutzen, J., Vitousek, P. M., Woodmansee, R. G., Goldberg, E. D., and Cook, R. B.: SCOPE 21 - the major biochemical cycles and their interactions, chap 1, in: Interactions of biochemical cycles, Workshop on the interactions of biogeochemical cycles, 2530 May 1981. 3962

Chillrud, S. N., Temporetti, P. F., and Planas, H. F.: Chemical weathering of phosphate and germanium in glacial meltwater streams: effects of subglacial pyrite oxidation, Limnol. Oceanogr., 39, 1130-1140, 1994. 3961

Concright, M. E., Gregg, W. W., and Levitus, S.: Seasonal cycle of phosphate in the open ocean, Deep-Sea Res. Pt. I, 47, 159-175, 2000. 3961, 3969, 3972, 3973

de Angelis, M., Steffensen, J. P., Legrand, M., Clausen, H., and Hammer, C.: Primary aerosol (sea salt and soil dust) deposited in Greenland ice during the last climatic cycle, comparison with East Antarctic records, J. Geophys. Res., 102, 26681-26698, 1997. 3963

de Boer, A. M., Watson, A. J., Edwards, N. R., and Oliver, K. I. C.: A multi-variable box model approach to the soft tissue carbon pump, Clim. Past, 6, 827-841, doi:10.5194/cp-6-8272010, 2010. 3972, 3974

Delaney, P.: Nutrients in glacial balance, Nature, 405, 288-291, 2000. 3962

20 tems, Science, 321, 926-929, 2008. 3962

Edwards, R., McConnell, J. R., and Banta, J. R.: Atmospheric deposition of iron and phosphorus to greenland over the 20th-century, AGU Fall Meeting Abstracts, B1154+, 2007. 3961, 3968

Elderfield, H. and Rickaby, R. E. M.: Oceanic Cd/P ratio and nutrient utilization in the glacial Southern Ocean, Nature, 405, 305-310, 2000. 3962

Elser, J. J., Cleland, C. E., Gruner, D. S., Harpole, W. S., Ngai, J. T., Seabloom, E. W., Shurin, J. B., and Smith, J. E.: Global analysis of nitrogen and phosphorus limitation of primary producers in freshwater, marine and terrestrial ecosystems, Ecol. Lett., 10, 1-8, 2007. 3961

Enghag, P.: Encyclopedia of the elements: technical data, history, processing, applications, Wiley-VCH, 1998. 3973
7, 3959-3989, 2011

\section{First phosphate data from Greenland ice cores}

H. A. Kjær et al.

\section{Title Page}

Abstract

Introduction

Conclusions

References

Tables

Figures
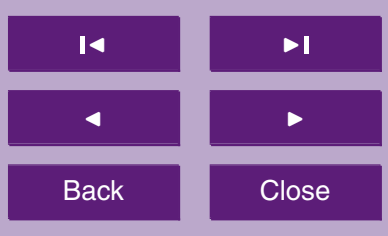

Back

Close

Full Screen / Esc

Printer-friendly Version

Interactive Discussion

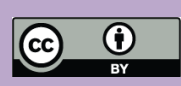


EPICA community members: Eight glacial cycles from an Antarctic ice core, Nature, 429, 623628, 2004. 3962

Falkowski, P. G., Barber, R. T., and Smetacek, V.: Biogeochemical controls and feedbacks on ocean primary production, Science, 281, 200-206, doi:10.1126/science.281.5374.200, 1998. 3961, 3962, 3974

Filippelli, G. M.: The global phosphorus cycle: past, present, and future, Elements, 4, 89-95, 2008. 3960, 3962

Filippelli, G. M., Souch, C., Menounos, B., Slater-Atwater, S., Tomothy Jull, A. J., and Slaymaker, O.: Alpine lake sediment records of the impact of glaciation and climate change on the biogeochemical cycling of soil nutrients, Quarternary Res., 66, 158-166, 2006. 3962

Fischer, H., Siggard-Andersen, M.-L., Ruth, U., and Röthlisberger, R. W. E.: Glacial-interglacial changes in mineral dust and sea-salt records in polar ice cores Sources transport and deposition, Rev. Geophys., 45, RG1002, doi:10.1029/2005RG000192, 2007. 3963

Fuhrer, K., Neftel, A., Anklin, M., Staffelbach, T., and Legrand, M.: High-resolution ammonium 15 ice core record covering a complete glacial inter-glacial cycle, J. Geophys. Res., 101, 41474164, 1996. 3963, 3974

Gianguzza, A., Pelizzetti, E., and Sammartano, S.: Chemistry of marine water and sediments, Springer, Berlin, 2002. 3972

Gimbert, L. J. and Worsfold, P. J.: Environmental applications of liquid-waveguide-capillary cells coupled with spectroscopic detection, Trac. Trend Anal. Chem., 26, 914-930, 2007. 3964

Graham, W. F. and Duce, R. A.: The atmospheric transport of phosphorus to the Western North Atlantic, Atmos. Environ., 16, 1089-1097, 1982. 3961

Graham, B., Guyon, P., Maenhaut, W., Taylor, P. E., Ebert, M., Matthias-Maser, S., MayolBracero, O. L., Godoi, R. H. M., Artaxo, P., Meixner, F. X., Moura, M. A. L., Rocha, C. H., Van Grieken, R., Glovsky, M. M., Flagan, R. C., and Andrea, M. O.: Composition and diurnal variability of the natural Amazonian aerosol, J. Geophys. Res., 108, 4765-4781, doi:10.1029/2003JD004049, 2003. 3973

Hansson, M. E.: The Renland ice core. A Northern Hemisphere record of aerosol composition over 120000 years, Tellus B, 46B, 390-418, 1994. 3963

30 Hodson, A., Mumford, P., and Lister, D.: Suspended sediment and phosphorus in proglacial rivers: bioavailability and potential impacts upon the $P$ status of ice-marginal receiving waters, Hydrol. Process., 18, 2409-2422, 2004. 3962, 3970
7, 3959-3989, 2011

\section{First phosphate data from Greenland ice cores}

H. A. Kjær et al.

\section{Title Page}

Abstract

Introduction

Conclusions

References

Tables

Figures
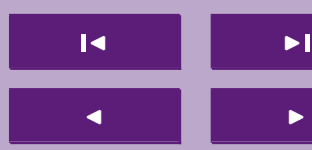

$\rightarrow$

$>$

Back

Close

Printer-friendly Version

Interactive Discussion 
Kaufmann, P. R., Federer, U., Hutterli, M. A., Bigler, M., Schupbach, S., Ruth, U., Schmitt, J., and Stocker, T. F.: An improved continuous flow analysis system for high-resolution field measurements on ice cores, Environ. Sci. Technol., 42, 8044-8050, 2008. 3964

Kreutz, K. J.: Glaciochemistry, in: Encyclopedia of Science, edited by: Elias, S. A., Elsevier Publishers, London, 2006. 3964

Lambert, F., Bigler, M., Steffensen, J. P., Hutterli, M., and Fischer, H.: The calcium-dust relationship in high-resolution data from Dome C, Antarctica, Clim. Past Discuss., 7, 1113-1137, doi:10.5194/cpd-7-1113-2011, 2011. 3970

Legrand, M. and Mayewski, P. A.: Glaciochemistry of polar ice cores: a review, Rev. Geophys., 35, 219-243, 1997. 3963

Levitus, S., Conkright, M. E., Reid, J. L., Naijar, R. G., and Mantyla, A.: Distribution of nitrate, phosphate and silicate in the world oceans, Prog. Oceanogr., 31, 245-273, 1993. 3961

Lüthi, D., Floch, M. L., Bereiter, B., Blunier, T., Barnola, J.-M., Siegenthaler, U., Raynaud, D., Jouzel, J., Fischer, H., Kawamura, K., and Stocker, T. F.: High-resolution carbon dioxide concentration record 650 000-800 000 years before present, Nature, 453, 379-382, 2008. 3974

Ma, J., Yuan, D., Zhang, M., and Liang, Y.: Reverse flow injection analysis of nanomolar soluble reactive phosphorus in seawater with a long path length liquid waveguide capillary cell and spectrophotometric detection, Talanta, 78, 315-320, 2009. 3965

Maher, B. A., Prospero, J. M., Mackie, D., Gaiero, D., Hesse, P. P., and Balkanski, Y.: Global connections between aeolian dust, climate and ocean biogeochemistry at the present day and last glacial maximum, Earth-Sci. Rev., 99, 61-97, 2010. 3963, 3970

Mahowald, N., Jickells, T. D., Baker, A. R., Artaxo, P., Benietz-Nelson, C. R., Bergametti, G., Bond, T. C., Ching, Y., Cohen, D. D., Herut, B., Kubilay, N., Losno, R., Luo, C., Maenhaut, W., McGee, K. A., Okin, G. S., Siefert, R. L., and Tsukuda, S.: Global distribution of atmospheric phosphorus sources, concentration and deposition rates, and anthropogenic impact, Global Biogeochem. Cy., 22, GB4026, doi:10.1029/2008GB003240, 2008. 3961, 3962, 3969, 3971, 3973

Mayewski, P. A., Meeker, L. D., Twickler, M. S., Whitlow, S. I., Yang, Q., Lyons, W. B., and Prentice, M.: Major features and forcing of high latitude northern hemisphere atmospheric circulation over the last 110000 years, J. Geophys. Res., 102, 26345-26366, 1997. 3963, 3968, 3987
7, 3959-3989, 2011

\section{First phosphate data from Greenland ice cores}

H. A. Kjær et al.

\section{Title Page}

Abstract

Introduction

Conclusions

References

Tables

Figures
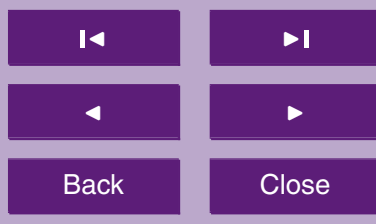

Back

Close

Printer-friendly Version

Interactive Discussion

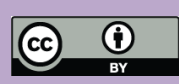


McConnell, J. R., Edwards, R., Kok, G. L., Flanner, M. G., Zender, C. S., Saltzman, E. S., Banta, J. R., Pasteris, D. R., Carter, M. M., and Kahl, J. D. W.: 20th-century industrial black carbon emissions altered arctic climate forcing, Science, 317, 1381, 2007a. 3963

McConnell, J. R., Edwards, R., Kok, G. L., Flanner, M. G., Zender, C. S., Saltzman, E. S., 5 Banta, J. R., Pasteris, D. R., Carter, M. M., and Kahl, J. D. W.: Microparticle and Trace Element Studies, Elsevier, London, 1207-1211, 2007b. 3963

Murphy, J. and Riley, J. P.: A single-solution method for the determination of soluble phosphate in sea water, J. Mar. Biol. Assoc. UK, 37, 9-14, 1958. 3964

NGRIP members: High-resolution record of Northern Hemisphere climate extending into the last interglacial period, Nature, 431, 147-151, 2004. 3962

Nollet, L. M. L.: Handbook of Water Analysis, 2nd Edn., CRC press, New York, 2007. 3965

Oelkers, E. H. and Valsami-Jones, E.: Phosphate mineral reactivity and global sustainability, Elements, 4, 83-87, 2008. 3962

Parekh, P., Joos, F., and Müller, S. A.: A modeling assessment of the interplay between aeolian iron fluxes and iron-binding ligands in controlling carbon dioxide fluctuations during Antarctic warm events, Paleoceanography, 23, 4202, 2008. 3974

Paytan, A. and McLaughlin, K.: The oceanic phosphorus cycle, Chem. Rev., 107, 563-576, 2007. 3960, 3961, 3962

Rasmussen, S., Andersen, K., Svensson, A. M., Steffensen, J. P., Vinther, B. M., Clausen, H. B., Siggaard-Andersen, M.-L., Johnsen, S. J., Larsen, L. B., Dahl-Jensen, D., Bigler, M., Röthlisberger, R., Fischer, H., Goto-Azuma, K., Hansson, M. E., and Ruth, U.: A new Greenland ice core chronology for the last glacial termination, J. Geophys. Res., 111, D06102, doi:10.1029/2005JD006079, 2006. 3968

Röthlisberger, R., Bigler, M., Hutterli, M., Sommer, S., Stauffer, B., Junghans, H. G., and Wagenbach, D.: Technique for continuous high-resolution analysis of trace substances in firn and ice cores, Environ. Sci. Technol., 34, 338-342, doi:10.1021/es9907055, 2000. 3964

Ruth, U.: Mineral dust records from Greenland ice cores, PAGES newsletter, 13, 17-20, 2005. 3963, 3970

Ruth, U., Wagenback, D., Steffensen, J. P., and Bigler, M.: Continuous record of microparticle concentration and size distribution in the Central Greenland NGRIP ice core during the last glacial period, J. Geophys. Res., 108, 4098, doi:10.1029/2002JD002376, 2003. 3970

Schlesinger, W. H.: Biochemistry, An analysis of global change, Academic press, London, 1991. 3962
7, 3959-3989, 2011

\section{First phosphate data from Greenland ice cores}

H. A. Kjær et al.

\section{Title Page}

Abstract

Introduction

Conclusions

References

Tables

Figures
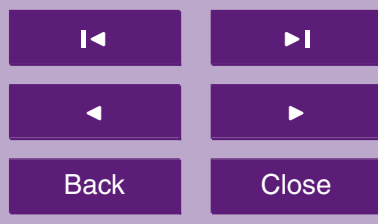

Back

Close

Printer-friendly Version

Interactive Discussion

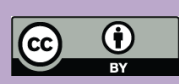


Sidall, M., Kaplan, M. R., Schaefer, J. M., Putnam, A., and Kelly, M. A.: Changing influence of Antarctic and Greenlandic temperature records on sea-level over the last glacial cycle, Quaternary Sci. Rev., 29, 410-423, 2010. 3974

Sigg, A., Fuhrer, K., Anklin, M., Staffelbach, T., and Zurmuehle, D.: A continuous analysis technique for trace species in ice cores, Environ. Sci. Technol., 28, 204-209, 1994. 3964

Steffensen, J. P.: The size distribution of microparticles from selected segments of the Greenland ice Core Project ice core representing different climatic periods, Analyst, 120, 187-191, 1997. 3970

Svensson, A., Biscaye, P. E., and Grousset, F. E.: Characterization of late glacial continental dust in the Greenland Ice Core Project ice core, J. Geophys. Res., 105, 4673-4556, 2000. 3963

Tamburini, F. and Föllmi, K. B.: Phosphorus burial in the ocean over glacial-interglacial time scales, Biogeosciences, 6, 501-513, doi:10.5194/bg-6-501-2009, 2009. 3961, 3962

Tiessen, H.: Phosphorus in the global environment: Transfers, Cycles and Management SCOPE 54, Wiley, Chichester, 1995. 3960, 3961, 3962, 3970

Tockner, K., Malard, F., Uehlinger, U., and Ward, J. V.: Nutrients and organic matter in glacial river-foodplain system (Val Roseg, Switzerland), Limnol. Oceanogr., 47, 266-277, 2002. 3961

Worsfold, P. J., Monbet, P., Tappin, A. D., Fitzsimons, M. F., Stiles, D. A., and McKelvie, I. D.: Characterisation and quantification of organic phosphorus and organic nitrogen components in aquatic system: a review, Anal. Chim. Acta, 624, 37-58, 2008. 3961

Zhang, J. and Chi, J.: Automated analysis of nanomolar concentrations of Phosphate in natural waters with liquid waveguide, Environ. Sci. Technol., 36, 1048-1053, 2002. 3964, 3965, 3966, 3975

Zhang, J. Z., Fischer, C. J., and Ortner, P. B.: Optimization of performance and minimization of silicate interference in continuous flow phosphate analysis, Talanta, 49, 293-304, 1999. 3964, 3965

Zielinski, G. A., Mayeski, P. A., Meeker, L. D., Whitlow, S., and Twickler, M. S.: A $110000-y r$ record of explosive volcanism from the GISP2 (Greenland) ice core, Quaternary Res., 45, 109-118, 1996. 3963
7, 3959-3989, 2011

\section{First phosphate data from Greenland ice cores}

H. A. Kjær et al.

\section{Title Page}

Abstract

Introduction

Conclusions

References

Tables

Figures
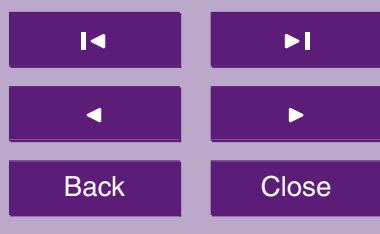

Back

Close

Full Screen / Esc

Printer-friendly Version

Interactive Discussion

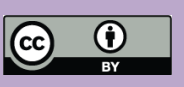


First phosphate data from Greenland ice cores

H. A. Kjær et al. calculated only for the depths where $\mathrm{PO}_{4}^{3-}$ was measured.

\begin{tabular}{|c|c|c|c|c|c|c|c|}
\hline Period & $\begin{array}{l}\text { Within } \\
\text { period }\end{array}$ & $\begin{array}{l}\text { depth interval } \\
\text { (m) }\end{array}$ & $\begin{array}{l}\mathrm{PO}_{4}^{3-} \\
(\mathrm{ppb})\end{array}$ & $\begin{array}{c}\sigma \\
(p p b)\end{array}$ & $\begin{array}{l}\delta D \\
(\% \circ)\end{array}$ & $\begin{array}{c}\text { Cond } \\
(\mu S / \mathrm{cm})\end{array}$ & $\begin{array}{c}\text { Dust } \times 10^{3} \\
(\text { Part. }>1 \mu \mathrm{m})\end{array}$ \\
\hline $\mathrm{A} 1$ & GS3 & $1607.70-1621.82$ & 24.1 & 2.8 & -339 & 3.03 & 159.2 \\
\hline $\mathrm{A} 2$ & GS3 & $1623.16-1626.25$ & 10.5 & 1.0 & -341 & 2.10 & 114.4 \\
\hline B1 & Gl3 & $1639.59-1640.62$ & 2.0 & 0.8 & -298 & 1.04 & 16.5 \\
\hline B2 & Gl4 & $1651.70-1654.00$ & 2.1 & 0.5 & -312 & 1.09 & 21.2 \\
\hline A3 & GS5 & $1657.20-1661.49$ and $1662.71-1666.96$ & 13.2 & 1.2 & -348 & 3.16 & 150.8 \\
\hline A4 & GS5 & $1675.91-1678.01$ and $1679.20-1680.41$ & 7.7 & 2.2 & -341 & 2.24 & 98.8 \\
\hline B3 & GI5 & $1684.72-1689.02$ & 0.7 & 0.4 & -312 & 0.99 & 14.5 \\
\hline A5 & GS6 & 1691.32-1693.37 and 1694.73-1695.50 & 6.4 & 1.1 & -339 & 2.14 & 94.4 \\
\hline B4 & Gl6 & $1697.90-1702.24$ & 1.6 & 0.2 & -309 & 1.06 & 13.9 \\
\hline A6 & GS7 & $1703.41-1709.87$ & 11.7 & 2.0 & -335 & 2.04 & 81.3 \\
\hline B5 & GI7 & $1717.73-1720.9$ & 1.7 & 0.6 & -304 & 0.96 & 11.9 \\
\hline A7 & GS8 & $1724.31-1728.6$ & 22.2 & 4.1 & -335 & 1.95 & 82.5 \\
\hline B6 & Gl8 & $1754.00-1756.11$ and $1757.29-1758.26$ & 0.8 & 0.5 & $\mathrm{n} \backslash \mathrm{a}$ & 1.01 & 9.8 \\
\hline A8 & GS9 & $1759.80-1764.94$ & 8.2 & 1.4 & $\mathrm{n} \backslash \mathrm{a}$ & 1.88 & 76.6 \\
\hline
\end{tabular}

Table 1. Mean values from the NEEM ice core for $\mathrm{PO}_{4}^{3-}$ as well as $\sigma$, the uncertainty introduced by baseline correction and the variability detected when measuring standards, $\delta \mathrm{D}$, Conductivity and Dust. The data has been determined for periods A within the cold glacial stadials (GS) and $B$ warmer glacial interstadials (GI) defined by the depth intervals in rows 3 to 6 . Means were
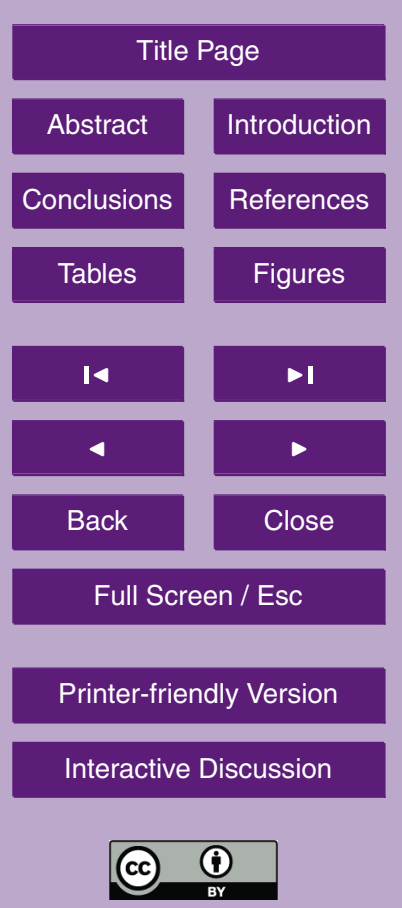


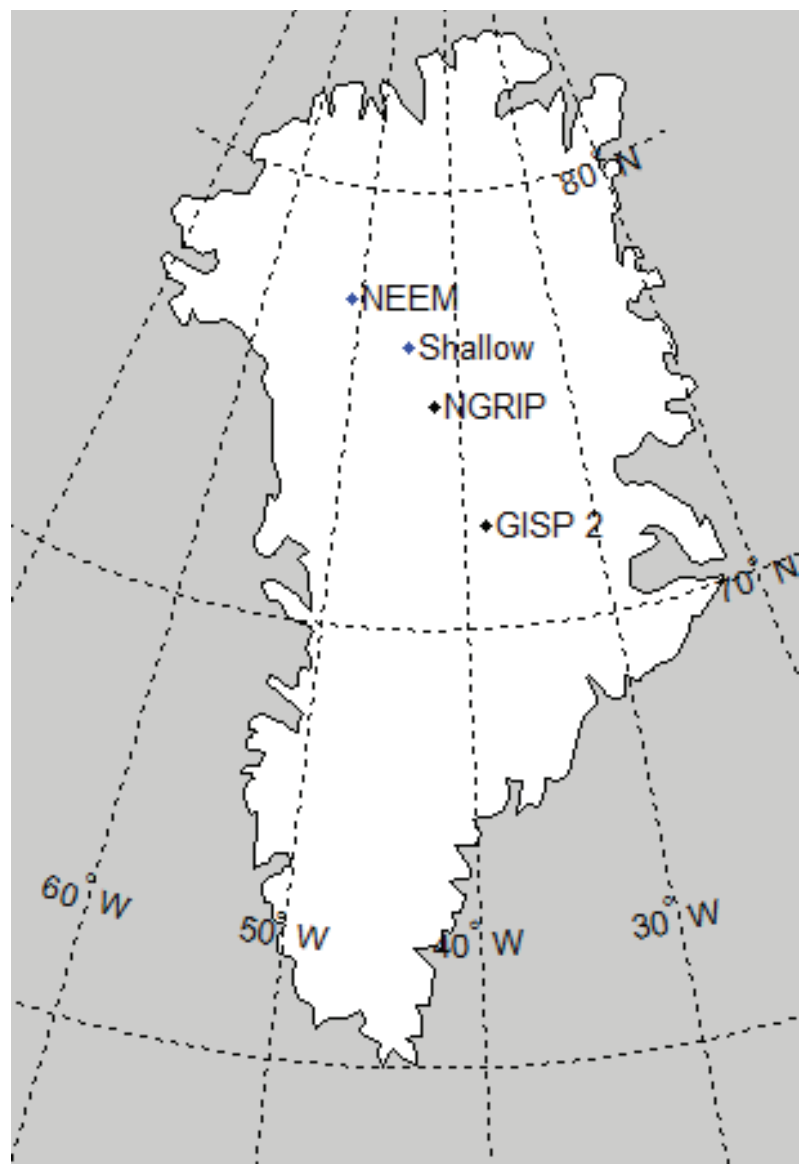

7, 3959-3989, 2011

First phosphate data from Greenland ice cores

H. A. Kjær et al.

Title Page

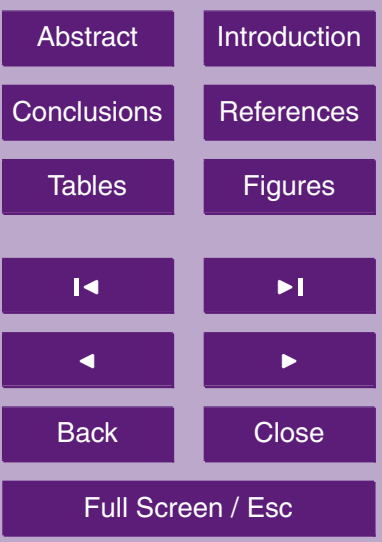

Printer-friendly Version

Fig. 1. Position of the ice cores used in this study. In blue the ice cores for which phosphate has been detected.

Interactive Discussion 


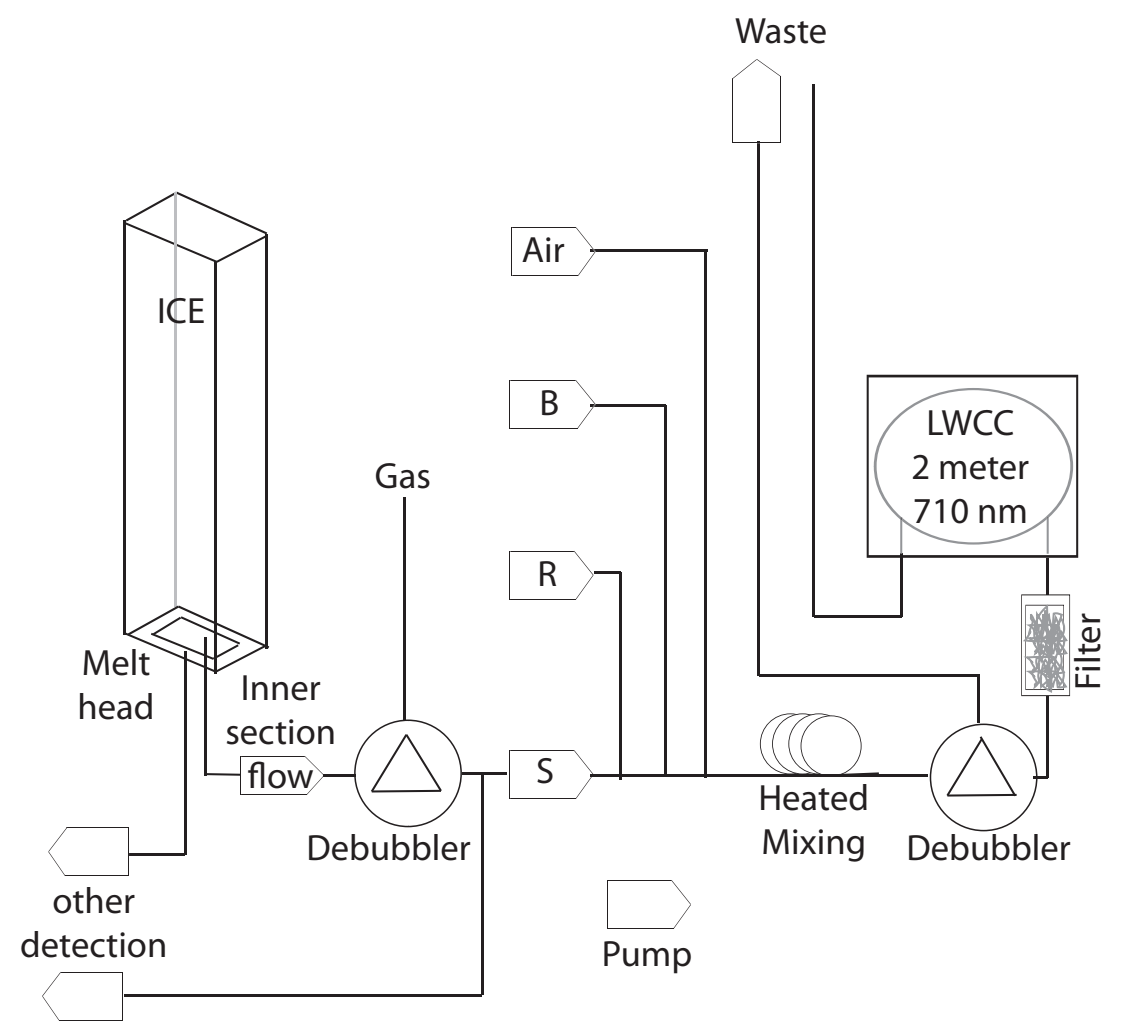

First phosphate data from Greenland ice cores

H. A. Kjær et al.

Title Page

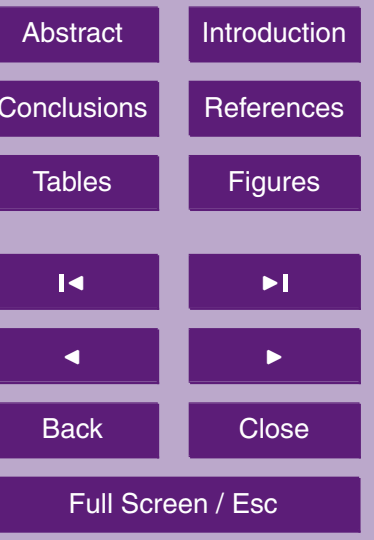

Printer-friendly Version

Interactive Discussion air. The sample is filtered to avoid optical interferences. Absorption at $710 \mathrm{~nm}$ is measured in a $2 \mathrm{~m}$ Liquid Waveguide Capillary Cell (LWCC).

\section{4}


Shallow firn core
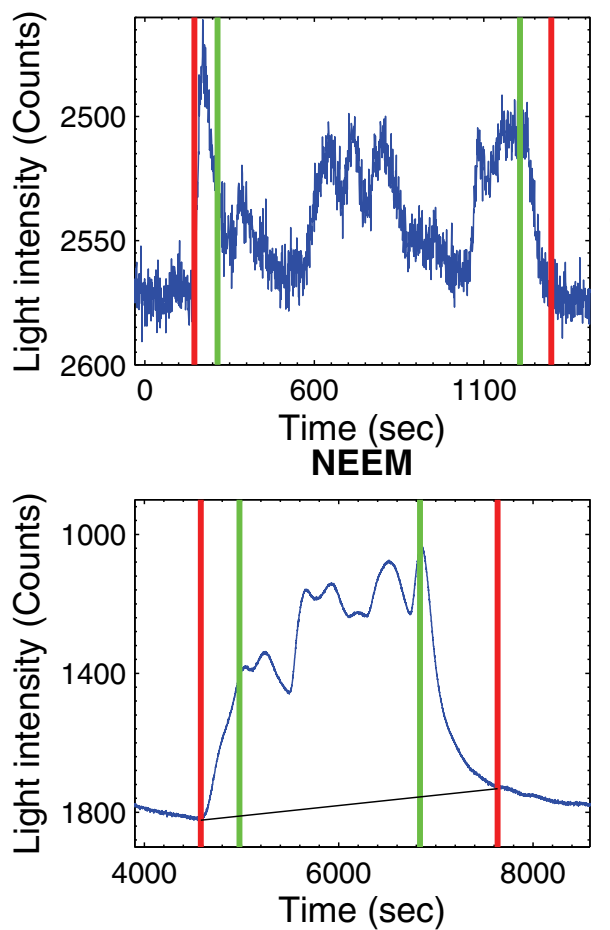

Shallow firn core
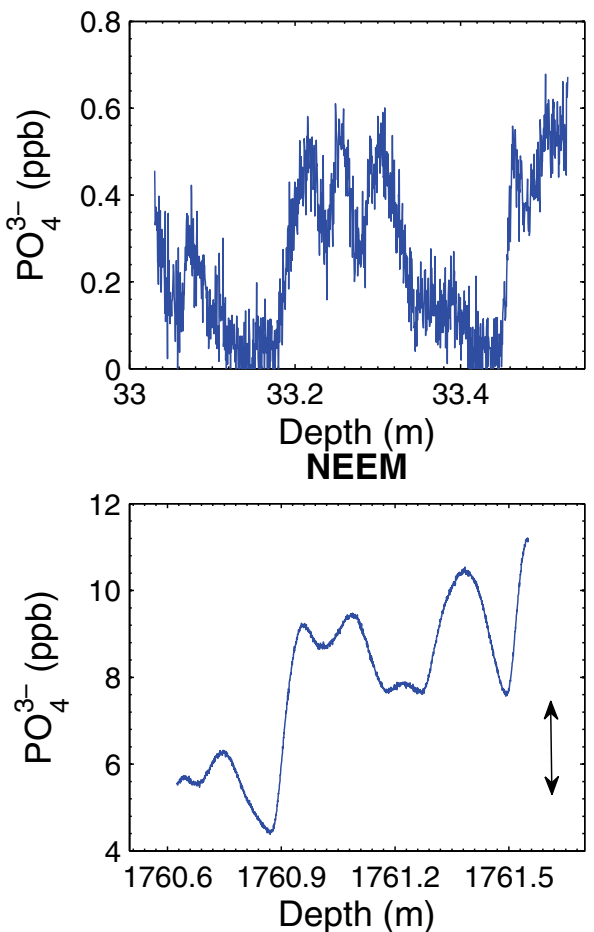

Fig. 3. Raw and calibrated $\mathrm{PO}_{4}^{3-}$ measurements from a shallow Greenland firn core and the NEEM ice core. Raw $\mathrm{PO}_{4}^{3-}$ data (left) are shown as light intensity (reversed scale) as a function of time. In the beginning and end of each sample there is a transition between baseline and sample which is removed (vertical lines). Calibrated datasets (right) are shown as $\mathrm{PO}_{4}^{3-}$ concentrations on a depth scale. The different light intensities between uncalibrated shallow firn and NEEM ice measurements reflect the different experimental conditions between the laboratory and field. The concentration uncertainty due to baseline correction is indicated by the double arrow. 

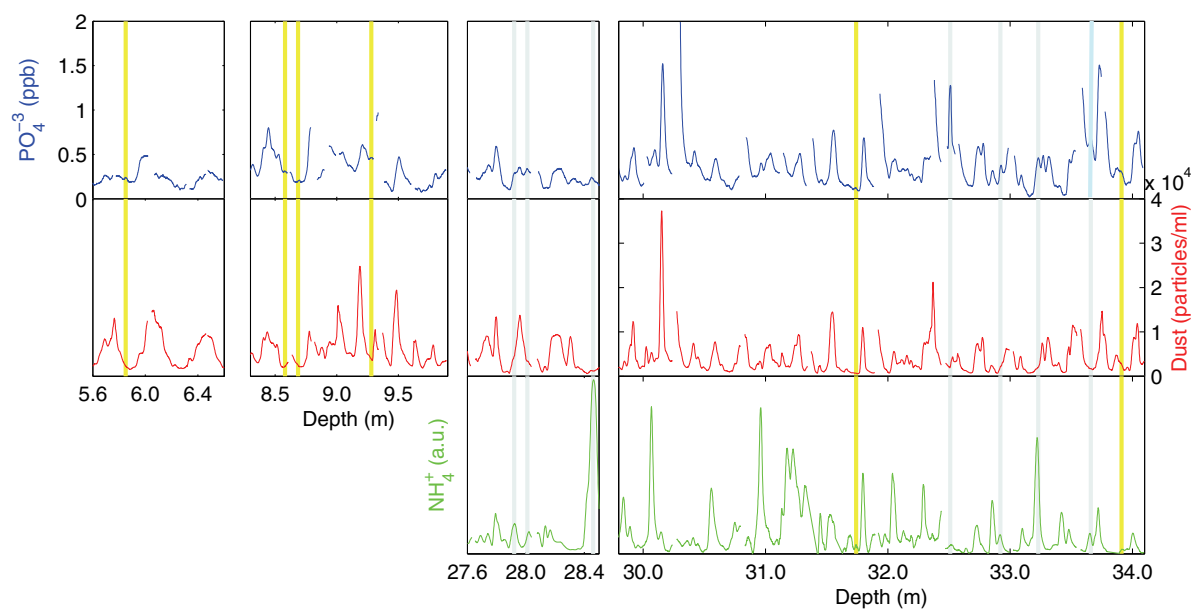

Fig. 4. Shallow firn core measurements from the depth span of $5.6 \mathrm{~m}$ to $34.1 \mathrm{~m}$ covering the period $1994 \mathrm{AD}$ to $1912 \mathrm{AD}$. The uppermost curve shows $\mathrm{PO}_{4}^{3-}$ (blue), the middle curve is dust (red) and the lowermost curve shows ammonium (green) measurements. The ammonium record shown here was not calibrated so it is reported qualitatively. The vertical yellow lines mark small bumps in the $\mathrm{PO}_{4}^{3-}$, which were not matched by dust. The vertical light blue lines mark $\mathrm{PO}_{4}^{3-}$ variations which were matched by variations in ammonium but not dust.
7, 3959-3989, 2011

\section{First phosphate data from Greenland ice cores}

H. A. Kjær et al.

\section{Title Page}

Abstract

Introduction

Conclusions

References

Tables

Figures

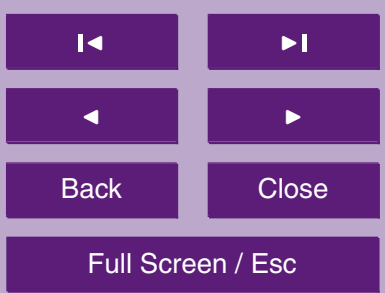

Printer-friendly Version

Interactive Discussion 


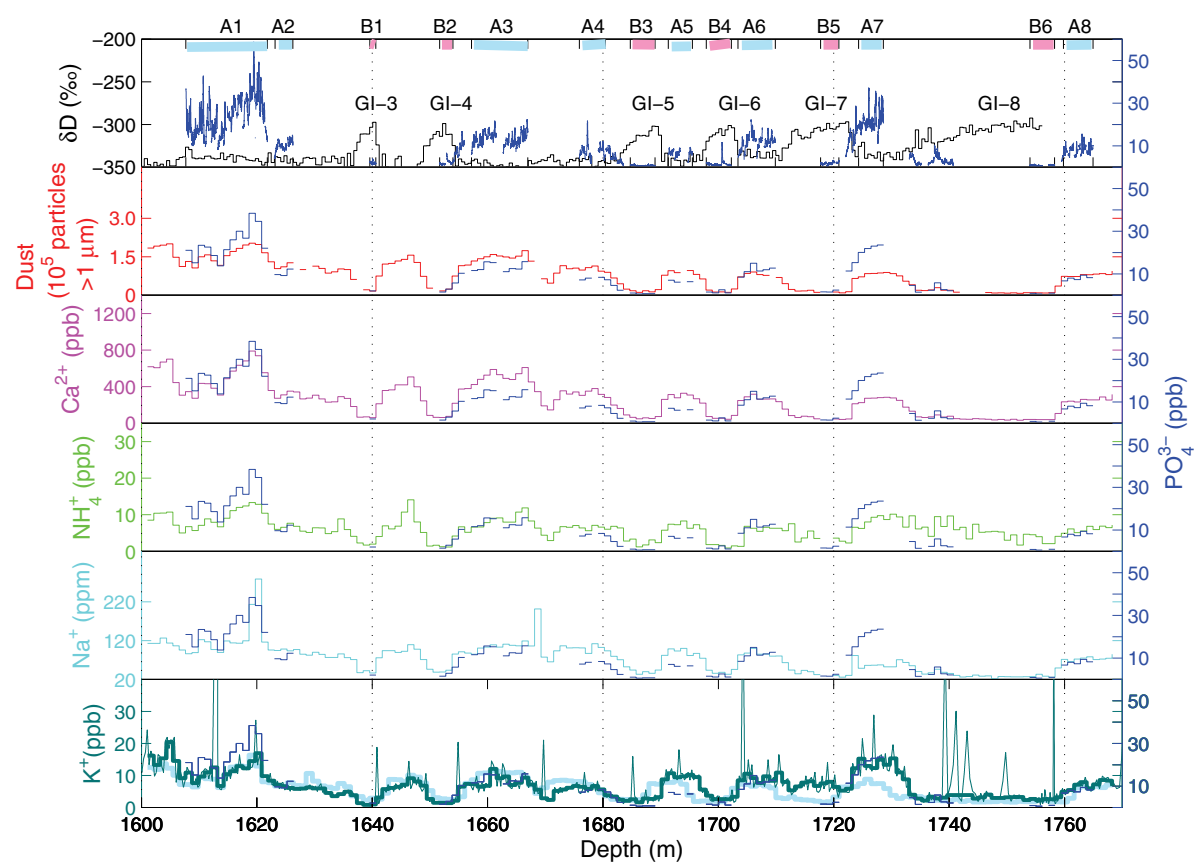

Fig. 5. $\mathrm{PO}_{4}^{3-}$ from NEEM (blue) plotted with $\delta D$ (black) in high resolution in the top panel, and as bag means with dust (red), $\mathrm{Ca}^{2+}$ (pink), $\mathrm{NH}_{4}^{+}$(green) and $\mathrm{Na}^{+}$(light blue) all from NEEM. In the bottom panel NEEM $\mathrm{PO}_{4}^{3-}$ is plotted with $\mathrm{K}^{+}$from NGRIP original (dark thin cyan) and means without spikes (dark thick cyan) and GISP2 (light thick cyan) (Mayewski et al., 1997) transferred to the NEEM depth scale. Note that all plots have the same $\mathrm{PO}_{4}^{3-}$ and depth scales but different scales for the individual species.
7, 3959-3989, 2011

\section{First phosphate data from Greenland ice cores}

H. A. Kjær et al.

\section{Title Page}

\section{Abstract}

Introduction

Conclusions

References

Tables

Figures

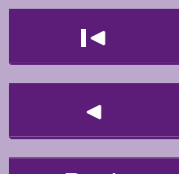

Back

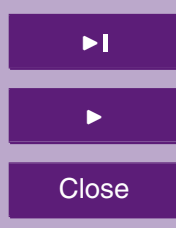

Full Screen / Esc

Printer-friendly Version

Interactive Discussion 


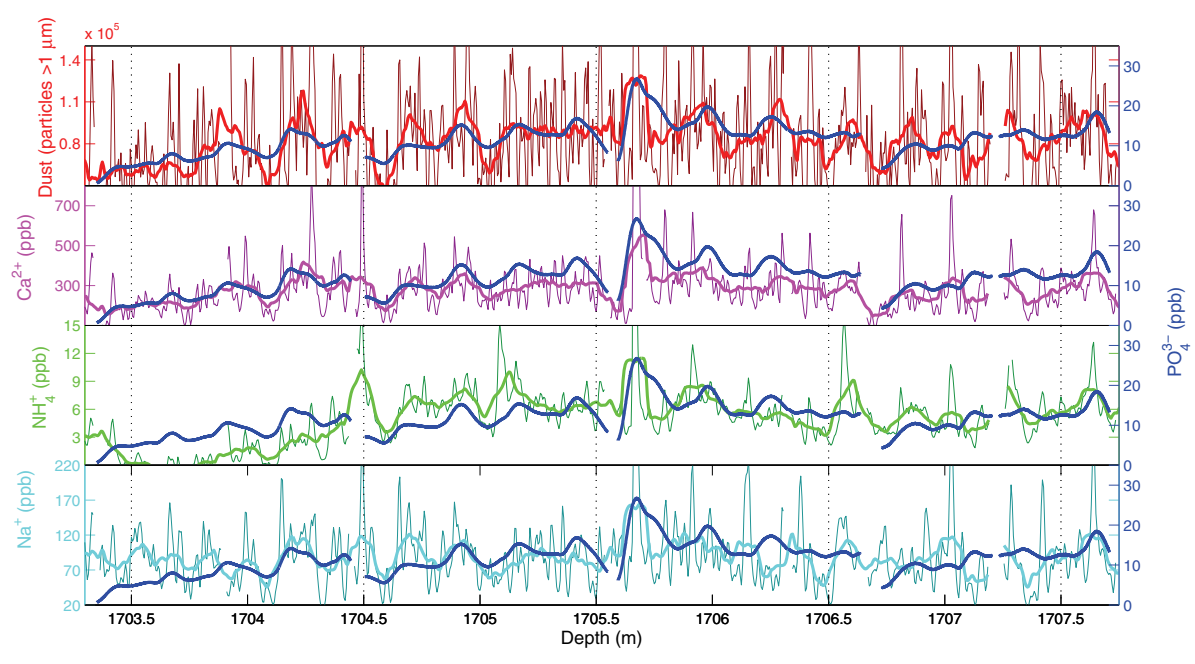

Fig. 6. High resolution CFA measurements from NEEM covering the transition to glacial interstadial 6, 1703.30 to $1707.75 \mathrm{~m}$ depth; $\mathrm{PO}_{4}^{3-}$ (blue), dust (red), $\mathrm{Ca}^{2+}$ (pink), $\mathrm{NH}_{4}^{+}$(green) and $\mathrm{Na}^{+}$(cyan). Thin and thick lines show the same data re-sampled at $0.5 \mathrm{~cm}$ and $5 \mathrm{~cm}$ depth resolution, respectively. The $0.5 \mathrm{~cm}$ resolution is provided, to compare timing of spikes, while $5 \mathrm{~cm}$ resolution shows the concentration level in a way that is more comparable to the level of $\mathrm{PO}_{4}^{3-}$.

\section{First phosphate data from Greenland ice cores}

H. A. Kjær et al.

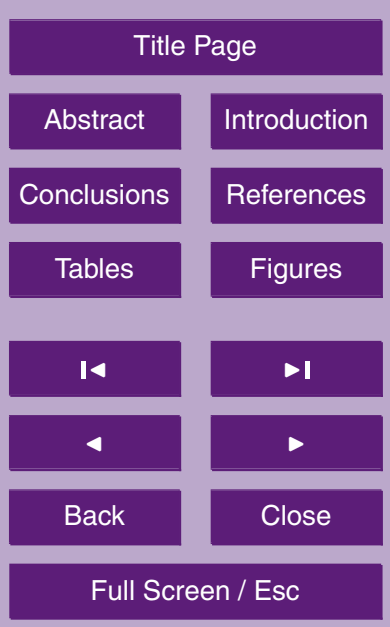

Printer-friendly Version

Interactive Discussion

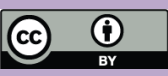



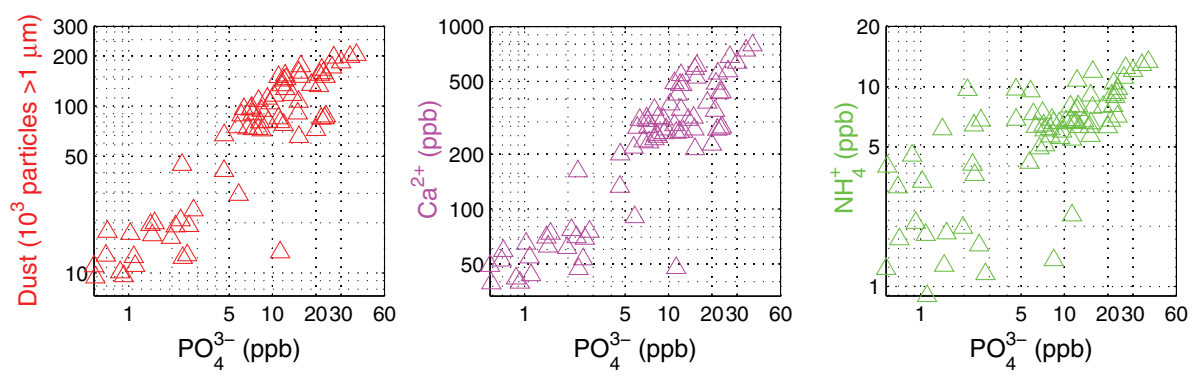

\section{First phosphate data from Greenland ice cores}

H. A. Kjær et al.
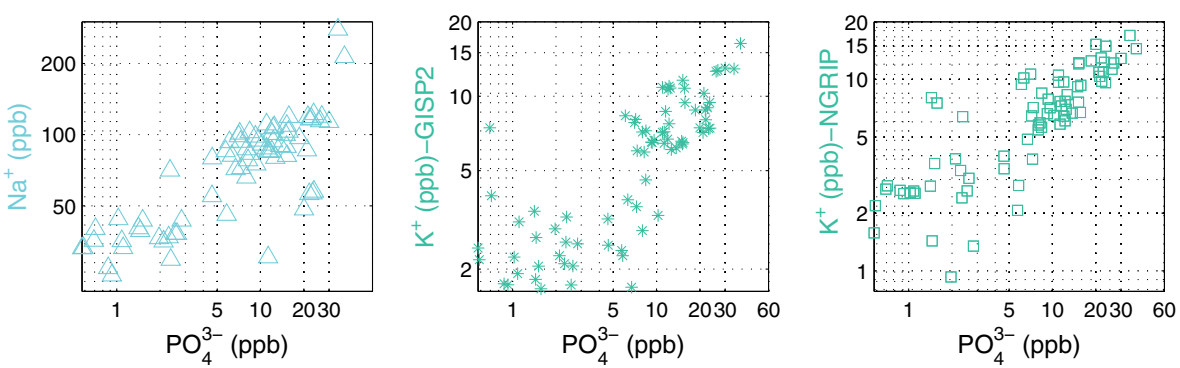

Title Page

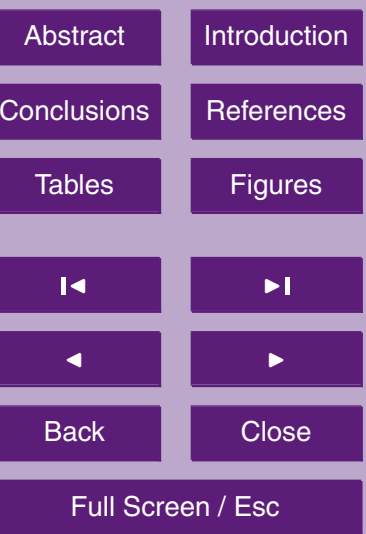

Fig. 7. Comparison of various CFA species determined in the NEEM ice core (triangles) and to $\mathrm{K}^{+}$determined with IC from the GISP2 ice core (stars) and NGRIP ice core (squares); $110 \mathrm{~cm}$ means are plotted against $\mathrm{PO}_{4}^{3-} 110 \mathrm{~cm}$ means. For $\mathrm{K}^{+}$-NGRIP (bottom, right) the 9 top excess spikes were removed from the $\mathrm{K}^{+}$before estimating means.

Printer-friendly Version

Interactive Discussion 